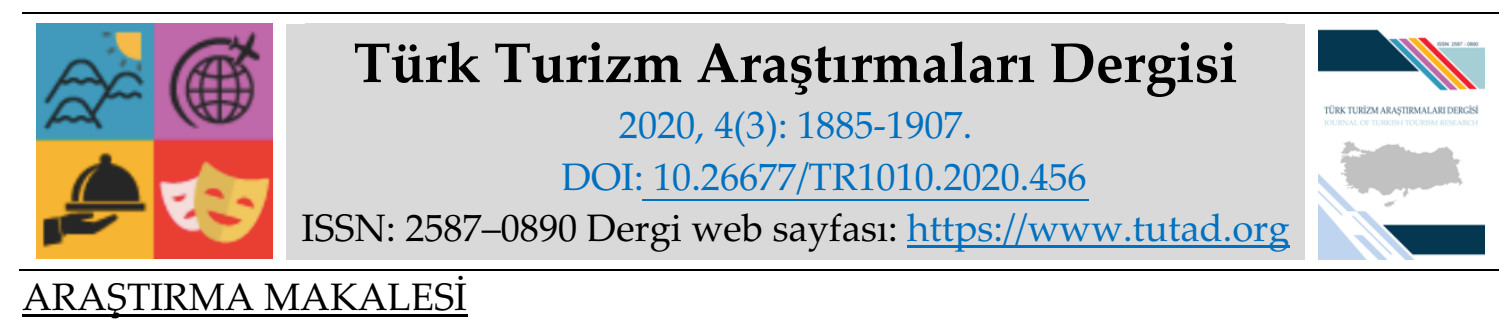

\title{
Turistik Noktalara İlişkin Ziyaretçi Fotoğraflarının Göstergebilimsel Açıdan Değerlendirilmesi ve Kamu Kurum Fotoğraflan ile Kıyaslanması
}

Dr. Öğr. Üyesi Çetin AKKUŞ, Kastamonu Üniversitesi, Turizm Fakültesi, Kastamonu, e-posta: cakkus@kastamonu.edu.tr ORCID: https://orcid.org/0000-0002-6539-726X

Savaş BÖYÜKYILMAZ, Doktora Öğrencisi, Kastamonu Üniversitesi, Turizm Fakültesi, Kastamonu, e-posta: sboyukyilmaz@ogr.kastamonu.edu.tr

ORCID: https://orcid.org/0000-0002-1162-2273

Öz

Bu çalışmanın amacı Kastamonu ilinde bulunan turistik noktaların ziyaretçi fotoğrafları ile il resmî kurumlarının tanıtım fotoğraflarını karşılaştırarak göstergebilimsel açıdan analiz etmektir. Araştırmada belirlenen 21 turistik nokta Instagram üzerinden taranmıştır. Toplamda 2008 adet fotoğraf içerik analizi yapılarak incelenmiştir. Fotoğraflar her nokta için kendi arasında beş gruba ayrılmıştır. En yüksek değeri alan grubun içerisinden sık tercih edilen arka plana ait fotoğraflardan biri seçilmiş ve resmi kurum sitelerindeki fotoğraflar ile karşılaştırılmıştır. Araştırmada, en fazla paylaşım yapılan turistik noktaların, doğal zenginliklere işaret ettiği görülmüştür. Bunlar; Horma Kanyonu (\%17,8), Ilgaz Dağ1 Milli Parkı (\%13,75), İnebolu Plajı $(\% 8,81)$, Küre Dağları Milli Parkı $(\% 8,42)$ ve Cide Gideros Koyu $(\% 7,82)$ olarak tespit edilmiştir. Ayrıca kamu kurumlarının fotoğraflarında ziyaretçilerin paylaştıkları fotoğraf açılarına benzerlik gösteren yedi turistik nokta saptanmıştır. Diğer turistik noktalarda daha az benzerlik ve çok az zıtlıklar görülmüştür. Araştırma sonucunda, Kastamonu destinasyonunda öne çıkan değerler vurgulanmış, bu turistik değerlerin hangi yönlerinin ziyaretçiler tarafından ön plana çıkarıldığı açiklanarak resmî kurumların tanıtım faaliyetlerinde fotoğraf kullanımı için önerilerde bulunulmuştur.

Anahtar Kelimeler: Göstergebilim, Sosyal Medya, Fotoğraf, Instagram, Kastamonu.

Makale Gönderme Tarihi: 30.02.2020

Makale Kabul Tarihi: 04.07.2020

\section{Önerilen Atıf:}

Akkuş, Ç. ve Böyükyılmaz, S. (2020). Turistik Noktalara İlişkin Ziyaretçi Fotoğraflarının Göstergebilimsel Açıdan Değerlendirilmesi ve Kamu Kurum Fotoğrafları ile Kıyaslanması, Türk Turizm Araştırmaları Dergisi, 4(3): 1885-1907.

(c) 2020 Türk Turizm Araştırmaları Dergisi. 


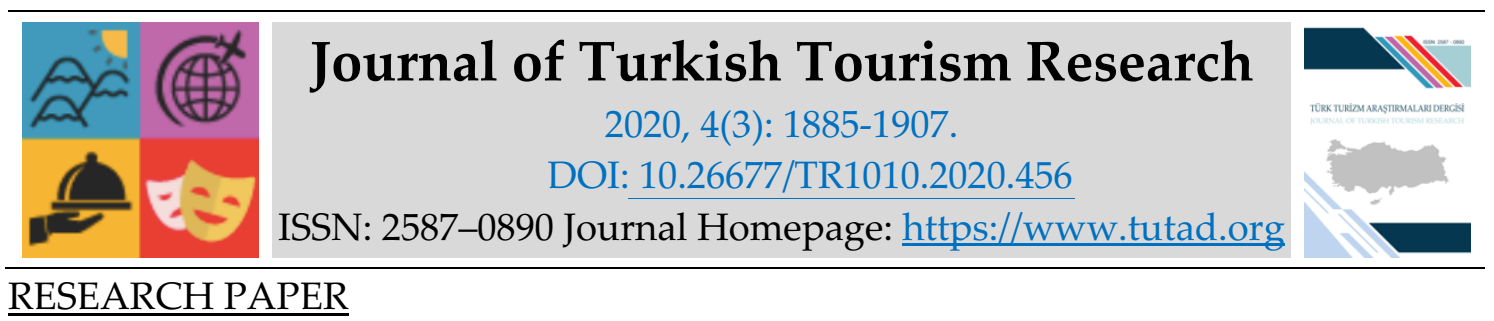

\title{
Semiotic Evaluation of Visitor Photographs Related to Touristic Points and Comparison with State Agency Photographs
}

Assistant Prof. Dr. Çetin AKKUŞ, Kastamonu University, Faculty of Tourism, Kastamonu, e-mail: cakkus@kastamonu.edu.tr

ORCID: https://orcid.org/0000-0002-6539-726X

Savaş BÖYÜKYILMAZ, Ph.D. Student, Kastamonu University, Faculty of Tourism, Kastamonu, e-mail: sboyukyilmaz@ogr.kastamonu.edu.tr

ORCID: https://orcid.org/0000-0002-1162-2273

\begin{abstract}
The purpose of this study is to analyze semiotic aspects by comparing the visitor photos of the touristic spots in Kastamonu Province and the promotional photos of the provincial official institutions. 21 touristic spots determined in the research were scanned on Instagram. A total of 2008 photographs were analyzed by content analysis. The photos are divided into five groups among themselves for each point. Among the group with the highest value, one of the frequently preferred background photos was selected and compared with the photos on official institution sites. The most shared tourist spots, natural riches are pointing. These; Horma Canyon (17.8\%), Ilgaz Mountain National Park (13.75\%), İnebolu Beach (8.81\%), Küre Mountains National Park $(8.42 \%)$ and Cide Gideros Bay $(7.82 \%)$ has been identified. In the photographs of public institutions, seven tourist spots that are similar to the photograph angles shared by the visitors were identified. Less similarities and fewer contrasts were detected at other tourist spots. In the research, it emphasized the prominent values in the Kastamonu destination, and which aspects of these touristic spots were highlighted by visitors, and suggestions were made for the use of photographs in the promotional activities of official institutions.
\end{abstract}

Keywords: Semiology, Social Media, Photography, Instagram, Kastamonu.

Received: 30.02 .2020

Accepted: 04.07.2020

\section{Suggested Citation:}

Akkuş, Ç. and Böyükyılmaz, S. (2020). Semiotic Evaluation of Visitor Photographs Related to Touristic Points and Comparison with State Agency Photographs, Journal of Turkish Tourism Research, 4(3): 1885-1907.

(C) 2020 Türk Turizm Araştırmaları Dergisi. 


\section{Gíriş}

Gelişen teknoloji ile ortaya çıkan önemli sosyo-kültürel değişikliklerin başında sosyal medya gelmektedir. Sosyal medya etkileşimin yüksek olduğu, kullanıcıların birbirleri ile iletişim kurabildikleri platformlardır. Bu platformlarda erişim kolay olmakla beraber etkileşim de oldukça yüksektir (Bedir Erişti, 2019:2). Oluşan çift taraflı ve eş zamanlı bilgi aktarımıyla artan etkileşim ortamı, ticari şirketlerin ve kurumların bu mecrayı etkin şekilde kullanmasını sağlamıştır. Dolayısıyla turizm şirketlerinin de teknolojiyi ve sosyal medyayı kullanmaları sonucunda turistlere ulaşmaları daha kolaylaşmıştır. Turistlerin paylaştıkları fotoğraflar, ziyaret ettikleri destinasyonun tanıtımını yapmakta ve bir cazibe merkezi haline gelmesine ortam hazırlamaktadır. Doğal bir pazarlama sistemi oluşturan bu durum destinasyonda yaşayan yerel halk ve resmi veya özel kurumların da paylaşımları ile birleştiğinde önemli bir etkileşim yaratmakta ve reklam değeri oluşturmaktadır. Bu nedenle turistik ürün hizmeti sağlayan ve tüketen bütün paydaşları tanımak ve birleştirmek giderek daha önemli hale gelmektedir.

Destinasyon ziyaretçilerinin bölgenin tanıtımını doğal yollarla yapması daha etkili sonuçlar elde edilmesini sağlar. Turistlerin destinasyonu tanıtmalarındaki ilk yol konuşma ve anlatımdır. Bunun yanında fotoğraf, internet, anında haberleşme yazılımları vb. yeni teknolojik gelişmeler de turistik destinasyonun tanıtılmasında oldukça önemlidir. Tüm bunların yorumlanması ve açıklanmasında ise göstergebilim kullanılabilir. Göstergebilim (semiyoloji) "gösterilenlerin bilimidir" ve mantıksaldır. İnsanların oluşturduğu gösterme sistemlerini açılayan bu bilimde medyada kullanılan metinler bütün halinde incelenir (Parsa ve Parsa, 2004:1). Bir başka yazara göre ise "Bir nesnenin ya da olgunun belli bir kesitinin belli bir zaman diliminde ve belli bir mekânda belli bir olgu veya nesne tarafindan gösterilmesidir" (Şahin, 2001:50). Dolayısıyla ziyaretçiler de gittikleri destinasyonda yaşadıkları eğlence, etkinlik, yemek, yerel hakla olan etkileşimleri ve daha birçok durumu fotoğrafları ile göstermektedirler.

Günümüzde akıllı cep telefonunun, fotoğraf makinesi ihtiyacını karşılıyor olması fotoğrafın yaygınlaşmasını sağlamıştır. Kişisel paylaşımlardan profesyonel paylaşımlara kadar her kesimi buluşturan sosyal medyanın gelişmesi ile de fotoğraf paylaşımı yaygın hale gelmiştir. Instagram fotoğraf paylaşım içeriği sağlaması açısından, bu alanda kullanılan en yaygın ve verimli ortamdır. İnsanların ziyaret ettikleri destinasyonlar ile ilgili paylaştıkları deneyimler, ulaştıkları geniş kitlelere bir bakış açısı sağlamakta ve ciddi anlamda etkileşimi olanaklı kılmaktadır. Ziyaretçilerin, destinasyonda ilgi duydukları kısımları tespit etmek önemlidir. Bu araştırmada, Kastamonu önemli doğal, tarihi ve turistik çekiciliklere sahip olması nedeniyle turist fotoğrafları içinde en çok paylaşımı yapılan Kastamonu çekiciliklerinin, göstergebilimden faydalanılarak yorumlanması amaçlanmıştır. Bu sayede en sık paylaşımı yapılan arka planlar, ziyaretçilerin bakış açısı ve beğenileri ile ilgili dikkat çekici veriler ortaya konulabilir. Bu durum yerel halkın turizmle kalkınmasını arzulayan resmi ve özel kurumların destinasyonu ön plana çıkarmak için yapacakları planlama ve çalışmalarda veri olarak kullanılabilir.

\section{LITERATÜR TARAMASI}

\section{Göstergebilim (Semiyoloji)}

Göstergebilim çalışmaları 20. yüzyılın başında ortaya çıkmıştır. Ferdinand de Sasure bu bilimi ortaya çıkaran bilim adamlarından biridir. İsviçre'de yaşamış olan Sasure'nin semiyoloji (semiology) olarak adlandırdığı bu bilim işaretler sistemi de sayılır. Aynı dönemlerde ABD'de yaşayan Charles Sanders Pierce, semiyotik (semiotics) kavramını kullanarak gösterilenlerin mantıkla olan ilişkisini açıklamaya çalışmıstır. Günümüze daha yakın olan bilim adamı Roland 
Barthes ise dilbilimin dişına çıkarak daha geniş anlamda; sesleri, nesneleri, görüntüleri ve anlam içeren her şeyi incelemiştir (Parsa ve Parsa, 2004: 1).

Daha önceleri dil bilimi ile ilişkilendirilen göstergebilim 1950'li yıllardan sonra başlı başına bir bilim olarak kabul görmeye başlamıştır. Bugün hala devam eden çeşitli uluslararası kongreler ile birlikte bilim olarak kabul edilmektedir. Yapılan ilk tanımlamalarda "bir şeyin yerine geçen bir şey" olarak tanımlanmıştır. Bununla birlikte, bakış açısı veya çağrışım yapma olarak da söylenegelen tanımlamalar olduğu bilinmektedir (Şahin, 2001:50). Bu nedenle anlatılanlar, sadece dilsel değil aynı zamanda birçok göstergeyi de içermektedir (Sı̆̆ırcı, 2016:39). Fransızcada semiyoloji tıp bilimde hastalıkların göstergelerini anlamak amacıyla da kullanılmaktadır. (Sığırcı, 2016:38). Diğer taraftan Sasure'ye göre toplumsal durumlar da göstergebilim açısından incelenebilir. Törenler, nezaket kuralları, sanat gibi toplumdaki insanlar tarafından kullanılan birçok iletişim biçimi de göstergebilimin konusuna dâhildir (Guiraud, 1999:17).

Gösterge oluşturmada gösteren ve gösterilen vardır. Biri anlatım düzlemi (gösteren) diğeri ise (gösterilen) içerik düzlemi ile ilgilidir. Gösteren ile gösterilenin birleşmesi de anlamlandırmadır (Barthes, 2005:44). Anlamlandırma iç içe olabilir. Bu durum sözcüklerin dizilmesi olan dizgelerle anlaşılır. Birinci dizilim düz anlamı ifade ederken ikinci dizge ise yan anlamı ifade eder (Barthes, 1986:82). Söz konusu yan anlam, çağrışım olarak adlandırılabilmektedir ve kullanıcının kendi içsel durumu ile ilgili olan öznel bir yargıdır. Dolayısıyla yan anlam, nedensiz olmakla beraber kişiye, kültüre, duygulara yönelik içerikler barındırır (Parsa ve Parsa, 2004:59). Herkes tarafından farkına varılamayıp anlamlandırılamayabilir. Ancak her göstergenin psikolojik bir çağrışım yapmasından dolayı mutlaka bir yan anlamı bulunmaktadır (Sığırcı, 2016:75). Böylece, yan anlam göstergeye özel bir değer katmaktadır. Örneğin çalışanın üzerindeki bir üniformanın belirli bir sınıfın temsili olması düz anlamı ifade ederken, saygınlık ve etkili görünmesi kişiye göre değişeceği için yan anlamı ifade etmektedir (Guiraud, 1999:45). Ancak gösterilenden çıkarılan anlam bireyseldir. Bu nedenle bir işaret ve nesne arasındaki ilişkinin ziyaretçinin üzerindeki etkisini pazarlamacıların incelemesi önemlidir. Dolayısıyla göstergebilimsel analiz bir destinasyonun olumlu yönlerini, kültürel ve sembolik anlamların oluşmasını sağlar (Pennington ve Thomsen, 2010:48).

\section{İLGİLİ ÇALIŞMALAR}

Çok karmaşık ve sınırsız sayıda reklam, afiş, gazete, dergi ve günümüzde bilişim araçları ile görsel gösterimler insanların yorumuna ve kullanımına sunulmaktadır. Sadece kurumların değil bireylerin de sayısız gösterimde bulunabildiği bilgi çağında bu bilimin önemi artmaktadır. Bir görüntüden yapılan içerik analizinde kişilerin yorumlarının derecelendirilmesi ve sınıflandırılması ile nicel duruma getirilebilir olması oldukça önemlidir (Parsa ve Parsa, 2004:131). Bunu yaparken de göstergebilimsel bir çözümleme yapılarak düz anlam, yan anlam ve üst dil kullanılabilir (Barthes, 2005:87). Bu durumda bir fotoğraftaki düz anlam ile birlikte kendi öz kültürleri ve bilişsel gelişmişlikleri ile fotoğrafa yükledikleri yan anlam, gösterenin ne denli anlamsal zenginlik oluşturabileceğini ortaya koymaktadır. Dolayısıyla ziyaretçinin (gösterenin) bir turistik fotoğrafa yüklediği düz anlam ve yan anlam ile kendi bakış açılarını ve öznel fikirlerini kullanması önemli bir veridir.

Ziyaretçilerin fotoğraf vb. paylaşımları ile oluşturduğu dijital içerik, doğal göstergebilimsel bir döngü yaratmaktadır. Dolayısıyla tüketicilerin davranışlarının daha kolay takip edilmesi sağlanabilir (Hunter, Chung, Gretzel ve Koo, 2015:113). Turistin destinasyonda yaşadığ deneyimi göstermiş olması da önemli bir detaydır. Ayrıca yerel halkın paylaştığı fotoğraflar, yaşantısına ilişkin verdiği bilgiler destinasyonun doğal tanıtımını yapabilmektedir (Davila ve Gretzel 2011:8). Bununla birlikte destinasyon yöneticileri tarafından resmî web sitelerinde 
modern mimari eserlerin büyük bir görüntüsünün sayfanın merkezine konulmasının da dikkat çekici olduğu belirtilmiştir. Fakat görüntülenen mimari eserin destinasyonun kimliği ile birlikte ele alınması gerektiği ortaya çıkmıştır. Böylece destinasyonun çok boyutlu ziyaretçiler için çekici olabileceği ifade edilmiştir (Godfrey ve Gretzel, 2010:10). Böylelikle turistlerin ziyaret ettikleri alanlar hakkında öğrenme ortamı bulmalarına, aynı destinasyonu tekrar ziyaret etmelerine, oluşturdukları sosyal birikim ile yerel toplumun içerisine dâhil olabilme olasılıklarının artmasına zemin oluşmaktadır (Knudsen ve Boyd, 2011:6).

Instagramda paylaşılan fotoğrafların destinasyondaki işlevsel durumları daha iyi ortaya koyduğu belirtilmektedir (Shuqair ve Cragg 2017:8). Lee, Lee, Moon ve Sung (2015) Kore'de 212 kullanıcı üzerinde yaptıkları araştırmada ınstagram kullanıcılarının motivasyonlarının; kendini ifade etme, sosyal etkileşim, arşivleme, kaçma ve gözetleme olduğu belirtilmiştir. Kullanıcıların çeşitli fotoğraflarla yaptıkları arşivlerinden kendi siber belgesellerini oluşturmayı değerli buldukları ortaya çıkmıştır. Arşivlerini ise günlük yaşantılarından kaçmak, başka insanlarla tanışmak ve etkileşim amacıyla kullandıkları görülmüştür. Diğer bir araştırmada da medya fotoğrafları analizinin artması gerektiği belirtilmiştir. Özel içerikler üzerinde daha iyi analizlerin yapılmasının, turizm deneyimlerinin iyileştirilmesine katkıda bulunabileceği belirtilmiştir (Picazo ve Moreno-Gil 2017:18). Endonezya'daki bir turizm sitesinin instagram sayesinde marka olma başarısını anlatan başka bir araştırmada, çeşitli etiketlerin (\#hastag) kullanımı sayesinde diğer turistlerin de paylaşılan fotoğrafları görebilmelerinin sağlanması, bilgilerin aranmasında önemli bulunmuştur. Etiketlerin anlatılmak istenen temanın daha özel hale gelmesinde etkili olduğu ve yeni turistik bölgelerdeki deneyimlerin aktarılması açısından önemli bir fırsat olduğu da çalışmanın diğer önerileri arasında yer almıştır (Fatani ve Suyadnya 2015:1092).

Peru'da yapılan bir araştırma sonucunda ziyaretçi paylaşımlarının daha çok yerel halkın günlük yaşantısını merak etme üzerine olduğu ancak destinasyon yöneticilerinin o zaman diliminden daha eski olan kültürel ve geleneksel yaşantıyı içeren fotoğrafları paylaştıkları görülmüştür (Stepchenkova ve Zhan, 2011:7). Fotoğraflar ziyaretçilerin önceliklerini öğrenebilmek adına önemlidir. Yine Porto Riko'da yapılan benzer bir araştırmada ise turistlerin bakış açıları ile yerel halkın bakış açılarının farklı olduğu tespit edilmiştir. Ziyaretçiler daha çok mimari yapıları, sokakları ve işaretleri gösterirken, yerel halkın çektiği fotoğraflarda ise daha çok doğal güzellikler ve diğer nesnelerin gösterildiği ifade edilmiştir (Davila ve Gretzel 2011:7).

2014 yılında Kopenhag şehrine ait bir etiket olan '\#sharingcph' ile coğrafi veriler mekânsal dağılım modeli ile sınıflandırılmıştır. Sonuçlar görüntüleri ve belirli özel noktalara olan dağılımları göstermektedir. Görüntülerin $\% 10^{\prime}$ u günbatımı ve su birikintisinden yansımaları ifade eden 'Biyokültürel Doğa' olarak sınıflandırılmıştır. İlk on önemli noktanın yeşil olması dikkat çekicidir. Görüntülerin \%44,4'ünün kentsel yeşil alanlarda çekildiği belirtilmiştir (Guerrero, Moller, Olafsson ve Snizek, 2016:7). 2016 yılında Saint Petersburg'da yapılan bir araştırmada ise Şubat ve Mart aylarına ilişkin turistlerin ınstagram paylaşımları incelenerek şehrin en sık ziyaret edilen bölgeleri tespit edilmeye çalışılmıştır. Sonuç olarak yerlilerin ve turistlerin farklı aktivite tercihlerine sahip oldukları bulunmuştur. Dolayısıyla ziyaretçilerin paylaşım yaptığı yerin turistik açıdan potansiyel taşıyabileceği belirtilmiştir (Mukhina, Rakitin ve Visheratin 2017:2382).

İsviçre'de yapılan bir araştırmada destinasyona ait 200 fotoğrafa içerik analizi yapılmış ve bölgeye ait sadece merkezi alanların değil tüm küçük büyük alanların daha fazla fotoğraflanmaya devam etmesi gerektiği belirtilmiştir. Ayrıca paylaşılan fotoğraflara konum etiketi eklenmesinin özellikle yiyecek fotoğraflarında önemli olduğu vurgulanmıştır. Dolayısıyla sosyal medya üzerinden viral pazarlama çalışması yapılabileceğine dikkat çekilmiştir (Golinvaux ve Evagelou, 2017:2). Erzincan'da yapılan araştırmada ise görsel ögelerden daha çok doğa sporlarının ön plana çıtığı görülmüştür. Destinasyon web sitesindeki görselin içeriğine uygun 
anahtar kelimelerin eklenmesi ile arama verilerine ulaşmanın kolaylaşması sağlanmakta olup destinasyon tanıtımlarında kullanılan fotoğrafların farklı açılardan gösterimlerinin yapılması ile zenginlik sağlanabileceği belirtilmiştir (Bayram, Keleş ve Bayram 2016:23).

Çin'de ziyaretçilerin algılarını keşfetmek için turist fotoğraflarının incelendiği araştırmada, Avrupalı turistlerin pandaları daha çok ön plana çıkardıkları, Amerikalı turistlerin ise basketbola daha çok ilgi gösterdikleri belirtilmiştir. Dağ fotoğraflarının ise daha çok Çin Seddi bölgesinde yoğunlaştığı belirtilmiştir. Dört kıtadan gelen turistlerin daha çok kentsel bina ve kültürel alanları ilk sırada tercih etmesine ek olarak bu alanlara ilişkin fotoğrafların geleneksel alanlar ile ilgili olduğu tespit edilmiştir. Dolayısıyla destinasyon yöneticilerinin farklı turistler için farklı deneyimler oluşturması gerektiği ortaya konulmuştur (Zhang, Chen ve Li 2019:606).

Yıl içerisinde yerli ve yabancı birçok turist ağırlayan Kastamonu, çok önemli turistik değerlere ve uzun tarihi geçmişe sahip bir şehirdir. Türkiye'nin Batı Karadeniz Bölgesinde yer alan Kastamonu M.Ö. 2000 yılından itibaren çeşitli uygarlıkların yaşam alanı olarak bilinmektedir (Kastamonu İl Kültür ve Turizm Müdürlügü̈, 2019). 13.108 km² yüzölçümüne sahip olan ilde yaklaşık 372.000 insan yaşamaktadır. Şehrin toplam 20 ilçesi olup altısı Karadeniz kıyı şeridindedir (KUZKA, 2019). Bitki örtüsü orman ağırlıklı olan şehirde kıyı kesimlerinde Karadeniz iklimi, iç kısımlarda ise karasal iklim etkilidir. Dağlık coğrafi yapısı yanında Karadeniz'e kıyısı olması şehre ayrı bir doğal zenginlik katmaktadır. Bununla birlikte turistik açısından birçok tarihi ve kültürel değere de sahiptir

Kastamonu'nun birçok çekiciliğe sahip olması yanı sıra araştırma kapsamında en çok fotoğraf paylaşımının yapıldığı 25 turistik nokta üzerinde çalışılarak ziyaret edilen alanın turist bakış açısıyla incelenmesi amaçlanmıştır. Bu nedenle belirlenen turistik noktalara ait fotoğrafları incelerken göstergebilimden faydalanılarak destinasyon pazarlamasında göz önüne alınabileceği düşüncesinden hareketle ziyaretçilerin bakış açıları tespit edilmeye çalışılmıştır.

\section{YÖNTEM}

\section{Araştırmanın Amacı}

$\mathrm{Bu}$ çalışmanın amacı Kastamonu ilinde bulunan turistik noktalara dair ziyaretçi fotoğrafları ile il resmî kurumlarının tanıtım fotoğraflarını karşılaştırarak göstergebilimsel açıdan analiz etmektir. Destinasyon tanıtımı açısından fotoğraf oldukça önemli bir unsurdur. Ancak bu durum ilgili kamu veya özel kuruluşlara ait web sitelerinde mutlaka bir fotoğraf bulundurulması gerektiği anlamına gelmemekle birlikte ziyaretçi fotoğraflarını anlayarak yapılacak pazarlama çalışmalarının daha etkili olabileceği varsayımından hareket edilmiştir.

\section{Veri Toplama Yöntemi}

Araştırmada içerik analizi yapılmıştır. İçerik analizi, toplanan verilerin kavramsal hale getirilmesi ve mantıksal bir düzen içerisinde açıklanmasıdır. Amaç, benzer olan verileri bir araya getirerek anlaşır bir şekilde düzenlemektir. Bunu yaparken de belirlenen kavramlar kategorize edilerek tümevarım yapılır (Yıldırım ve Şimşek 2016:242). Yapılan literatür taramasından sonra araştırmada göstergebilimden yararlanılması uygun bulunmuştur.

\section{Araştırmanın Kapsamı ve Sınırlılıkları}

Araştırmanın kapsamını Kastamonu etiketi ile sosyal medyada paylaşılan fotoğraflar oluşturmaktadır. Sosyal medyanın farklı kanallarında milyonlarca fotoğrafın varlığı göz önünde bulundurularak araştırma, en çok tercih edilen platform olan ınstagram'la sınırlandırılmıştır. 
Ziyaretçilerin süreç içerisinde paylaştıkları fotoğrafları silmeleri ya da tekrar paylaşmaları ve tarama esnasında web sitelerinin yavaşlaması gibi durumlar bir nokta için yapılan taramanın tek seferde yapılıp bitirilmesini zorunlu kılmıştır. Ayrıca ziyaretçilerin paylaştıkları fotoğraflarda kendilerinin veya yakınlarının da bulunmasından dolayı izinsiz yayınlanamayacağı için benzer en yakın fotoğrafın seçilmesi çalışmanın bir diğer sınırlılığını oluşturmuştur.

\section{Evren ve Örneklem}

Kastamonu'da birçok turistik çekim noktası bulunmasına rağmen kamu kuruluşları (Valilik, Belediye, İl Kültür ve Turizm Müdürlüğü) resmi web sitelerinden yaklaşık 60 turizm noktası belirlenmiştir. Ancak bu noktaların hepsinin değerlendirilmesi, yoğunlaşmayı zorlaştıracağ için en çok fotoğraf paylaşımı yapıldığı tespit edilen 25 noktaya indirgenmiştir. Yapılan ön çalışmada instagramda Ekim 2018 ila Ekim 2019 arasında 52 hafta boyunca paylaşılmış toplam 2046 fotoğraf tespit edilmiştir. Belirlenen noktalardan dört tanesine ilişkin çok az sayıda veya hiç fotoğraf bulunmaması ya da bulunan fotoğrafların değerlendirilmesi yapılacak kadar bölgeyi temsil etmemesi nedeniyle bu noktalar araştırmadan çıkarılmıştır. Kalan 21 turistik noktaya ait 2008 fotoğraf üzerinden inceleme yapılmasına karar verilmiştir. Yapılan incelemede fotoğraflar iki aşamada sınıflandırılmıştır. Bunlar;

Fotoğrafların Belirlenen Turistik Noktalara Göre Sinıflandırılması: Araştırmada belirlenen 21 nokta ınstagram üzerinden taranmıştır. Taramalar yapılırken sosyal ağlarda ve mikroblog bir sözcük ya da sözün başına diyez işareti eklenerek oluşturulan (Wikipedia, 2019) etiket kullanılmıştır. Taramada \#Horma Kanyonu, \#Ilgaz Dağı Milli Parkı, \#İnebolu Plajı, \#Küre Dağları Milli Parkı, \#Cide Gideros Koyu, \#Ginolu Plajı, \#Valla Kanyonu, \#Loç Vadisi, \#Kurşunlu Han, \#Şerife Bacı Anıtı, \#Ilgarini Mağarası, \#İstiklal Yolu, \#Kale, \#Nasrullah Meydanı, \#Mahmut Bey Cami, \#Evkaya Mezarı, \#Saat Kulesi, \#Pompeiopolis (Zimbıllı), \#Kastamonu Merkez, \#Beldeğirmen Köyü, \#Etnografya Müzesi ve ayrıca her nokta için \#Kastamonu etiketleri kullanılarak aramalar sonucu bulunan fotoğraflar ayrı klasörlerde toplanmıştır.

Sinıflandırılan Fotoğrafların Kendi İçerisinde Gruplandırılmast: 21 turistik noktaya ait toplam 2008 fotoğraf analiz edilmiştir. Her bir nokta için ayrılan fotoğraflar kendi içerisinde fotoğrafın arka plan görüntüsüne göre yeşil veya karlı alan, yol, bina veya su alanı, ufuk çizgisi veya geniş bir manzarayı gösteren açık alan, fotoğraf karesinde ziyaretçi dışında birden fazla kişinin bulunması, araç, eşya vb. başka unsurların bulunması ile oluşan karmaşık alan olmak üzere beş kategoriye ayrılmıştır. Ardından frekansları alınmış ve alanda en çok paylaşılan fotoğraf teması temsili olarak seçilmiştir. Bununla birlikte resmî kurumlardan Belediye, Valilik ve İl Kültür ve Turizm Müdürlüğü resmî web sitelerinde yer alan ilgili alan fotoğrafı seçilerek bu fotoğraflarla karşılaştırılmıştır.

\section{Verilerin Analiz Edilmesi}

Göstergebilimsel çözümleme yaparken, düz ve yan anlamlandırma kullanılmaktadır. Düz anlamda ilk görülenlerin hiçbir zaman kaybolmadığı bilinmekle beraber yan anlam her zaman bulunmayabilir (Barthes, 2005:87). Bu durumda, bir fotoğraf düz anlamın yanında yan anlam içerebilmekte ve gösterilen fotoğrafı inceleyenler düz anlam ile birlikte kendi öz kültürleri ve bilişsel gelişmişlikleri ile fotoğrafa yükledikleri yan anlam gösterenin ne denli çok anlamsal bir zenginlik oluşturabileceğini ortaya koymaktadır. Dolayısıyla ziyaretçinin (gösterenin) bir turistik fotoğrafa yüklediği düz anlam ve yan anlam ile kendi bakış açılarını ve öznel fikirlerini anlatmış olması önemli bir veridir. Dolayısıyla tüketicilerin davranışlarının daha kolay takip edilmesi sağlanabilmektedir (Hunter vd., 2015:113). 
$\mathrm{Bu}$ araştırmada, yazarlar önce ziyaretçinin fotoğraf karesindeki arka planı, daha sonra varsa resmî kurumlara ait fotoğrafları aynı parametrelerle değerlendirmiştir. Ardından bu iki grup göstergebilim yardımı ile düz ve yan anlam açısından karşılaştırılmıştır. Son olarak, fotoğraflara ilişkin yazarların yorumları birlikte değerlendirilmiş ve ortak bir metin haline getirilerek çalışmada sunulmuştur.

\section{BULGULAR}

Kastamonu turistik çekim noktalarından belirlenen 21 alan analizi Tablo 1'de verilmiştir. Bu verilere göre en çok fotoğraf $(\% 17,08)$ paylaşımının yapıldığı turistik nokta Horma Kanyonu'dur. Bunu \%13,75 ile Ilgaz Dağı Milli Parkı ve \%8,81 ile İnebolu Plajı takip etmektedir. Küre Dağları Milli Parkı çok yakın bir oranla $(\% 8,41)$ fotoğraf paylaşılan dördüncü turistik noktadır. Ziyaretçilerin paylaşımda bulunduğu ilk beş turistik nokta toplam paylaşım oranının yaklaşık yarısını oluşturmakta olup, tamamı doğal zenginliklere ve çekiciliklere işaret etmektedir. Ayrıca iki doğal park, iki deniz kıyısı ve bir kanyonun yer alması ziyaretçilerin Kastamonu'nun sadece bir turistik ürününe ve aynı zamanda bir turistik bölgesine yoğunlaşmadıklarını, daha çok doğal turistik ürünlere yoğunlaştıklarını göstermektedir. Bunlar içerisinde jeolojik bir turistik değerin birinci sırada yer alması ise dikkat çekicidir.

İkinci beş paylaşım noktası incelendiğinde, Cide Gideros Koyu ziyaretçilerin paylaşım yaptığı altınc1 $(\% 7,82)$ nokta olmakla beraber yedinci olan Ginolu Plajı ile yakın oranlara $(\% 7,42)$ sahiptir. Kastamonu'da yer alan bir diğer kanyon olan Valla Kanyonuna dair ziyaretçilerin paylaştıkları fotoğraflar incelendiğinde $\% 5,53$ oranında paylaşımda bulundukları görülmektedir. Bu durumu takip eden Loç Vadisi $(\% 4,53)$ sekizinci paylaşım noktasını oluşturmaktadır. Hemen ardından birbirlerine çok yakın oranlarda Kurşunlu Han $(\% 3,59)$ ve Şerife Bacı Anıtı $(\% 3,49)$ fotoğrafı paylaşımı dikkat çekmektedir. Bu bölümde plaj, kanyon, vadi ve iki kültürel mirasa ait turistik çekicilik yer almakla beraber kültürel ürünlerin son iki ( 8 ve 9) sırayı paylaşıyor olması Kastamonu'nun doğal zenginliklerinin önemli bir çekiciliğe sahip olduğunu teyit etmektedir. Ayrıca bu beş turistik noktanın üçünde farklı alanların fotoğrafının paylaşılması da önemli bir bulgu olarak değerlendirilebilir.

Ziyaretçilerin paylaşımda bulundukları onuncu turistik nokta \%2,69 ile Ilgarini Mağarası olup yine doğal ve jeolojik turistik ürün olarak dikkati çekmektedir. Ziyaretçilerin daha sonraki dört paylaşımının da kültürel ürünleri ortaya çıkardığı görülmektedir. Bunlar sırası ile İstiklal Yolu $(\% 2,64)$, Kastamonu Kalesi (\%2,59), Nasrullah Meydanı (\%2,44) ve Mahmut Bey Camii'dir $(\% 1,94)$. Ziyaretçilerin 10 ila 14 arasındaki beş turistik noktaya ait paylaşımlarında kültürel mirasa ait ürünlerin hâkim olduğu görülmektedir. Bu durumu takiben fotoğraf paylaşımı yapılan ürünlerde binaya ait fotoğraf paylaşımı yaygındır. Ziyaretçilerin paylaşımlarında Evkaya Mezarları 16. sırada olup \%1,74 oranında fotoğraf paylaşımına sahiptir. Kastamonu Saat Kulesi paylaşımları ve Pompeipolis veya diğer adıyla Zımbıllı Tepe Höyüğü \%1,44 ile aynı orana sahiptir.

Kastamonu merkeze ait fotoğraf paylaşımları \%1,25 ile 19. sırada yer almaktadır. Ziyaretçilerin paylaşımlarında Bel Değirmen Köyü $(\% 0,95)$ ve Etnografya Müzesi $(\% 0,5)$ son iki sıradadır. Paylaşılan fotoğraflarda tarihi ve kültürel miras ürünlerinin doğal miras ürünlerinden sonra geldiği tespit edilmiştir. 
Tablo 1. Kastamonu İli Turistik Çekim Noktalarına Ait Paylaşılan Fotoğraflara İlişkin İstatistikler

\begin{tabular}{|c|c|c|c|c|c|c|c|c|c|c|c|c|c|}
\hline & \multirow[b]{2}{*}{ Bölgeler } & \multicolumn{2}{|c|}{$\begin{array}{c}\text { Yeşil -Kar } \\
\text { Alanı }\end{array}$} & \multicolumn{2}{|c|}{$\begin{array}{c}\text { Yol } \\
\text { Alanı } \\
\end{array}$} & \multicolumn{2}{|c|}{$\begin{array}{c}\text { Bina-Su } \\
\text { Alanı } \\
\end{array}$} & \multicolumn{2}{|c|}{$\begin{array}{l}\text { Açık } \\
\text { Alan } \\
\end{array}$} & \multicolumn{2}{|c|}{$\begin{array}{c}\text { Karışık } \\
\text { Alan }\end{array}$} & \multicolumn{2}{|c|}{ Genel } \\
\hline & & $\mathbf{f}$ & $\%$ & $\mathbf{f}$ & $\%$ & $\mathbf{f}$ & $\%$ & $\mathbf{f}$ & $\%$ & $\mathbf{f}$ & $\%$ & $\mathbf{f}$ & $\%$ \\
\hline 1 & Horma Kanyonu & 83 & 24,2 & 160 & 46,7 & 66 & 19,2 & 15 & 4,37 & 19 & 5,54 & 343 & 17,1 \\
\hline 2 & Ilgaz Dağ1 Milli P. & 110 & 39,9 & 42 & 15,2 & 13 & 4,71 & 58 & 21 & 53 & 19,2 & 276 & 13,8 \\
\hline 3 & İnebolu Plaj1 & 7 & 3,95 & 1 & 0,56 & 1 & 0,56 & 100 & 56,5 & 68 & 38,4 & 177 & 8,81 \\
\hline 4 & Küre Dağları Milli P. & 40 & 23,7 & 18 & 10,7 & 24 & 14,2 & 76 & 45 & 11 & 6,51 & 169 & 8,42 \\
\hline 5 & Cide-Gideros Koyu & 42 & 26,8 & 6 & 3,82 & 16 & 10,2 & 47 & 29,9 & 46 & 29,3 & 157 & 7,82 \\
\hline 6 & Ginolu Plaj1 & 48 & 32,4 & 0 & 0 & 32 & 21,6 & 16 & 10,8 & 52 & 35,1 & 148 & 7,37 \\
\hline 7 & Valla Kanyonu & 10 & 9,01 & 28 & 25,2 & 13 & 11,7 & 42 & 37,8 & 18 & 16,2 & 111 & 5,53 \\
\hline 8 & Loç Vadisi & 35 & 38,5 & 3 & 3,3 & 26 & 28,6 & 26 & 28,6 & 1 & 1,1 & 91 & 4,53 \\
\hline 9 & Kurşunlu Han & 14 & 19,4 & 5 & 6,94 & 15 & 20,8 & 6 & 8,33 & 32 & 44,4 & 72 & 3,59 \\
\hline 10 & Şerife Bacı Anıtı & 9 & 12,9 & 0 & 0 & 4 & 5,71 & 46 & 65,7 & 11 & 15,7 & 70 & 3,49 \\
\hline 11 & Ilgarini Mağarası & 26 & 48,2 & 18 & 33,3 & 7 & 13 & 1 & 1,85 & 2 & 3,7 & 54 & 2,69 \\
\hline 12 & İstiklal Yolu & 7 & 13,2 & 15 & 28,3 & 10 & 18,9 & 7 & 13,2 & 14 & 26,4 & 53 & 2,64 \\
\hline 13 & Kastamonu Kalesi & 0 & 0 & 1 & 1,92 & 0 & 0 & 41 & 78,9 & 10 & 19,2 & 52 & 2,59 \\
\hline 14 & Nasrullah Meydanı & 14 & 28,6 & 20 & 40,8 & 14 & 28,6 & 0 & 0 & 1 & 2,04 & 49 & 2,44 \\
\hline 15 & Mahmut Bey Cami & 7 & 18 & 14 & 35,9 & 13 & 33,3 & 0 & 0 & 5 & 12,8 & 39 & 1,94 \\
\hline 16 & Evkaya Mezarı & 2 & 5,71 & 2 & 5,71 & 25 & 71,4 & 0 & 0 & 6 & 17,1 & 35 & 1,74 \\
\hline 17 & Saat Kulesi & 2 & 6,9 & 6 & 20,7 & 9 & 31 & 3 & 10,3 & 9 & 31 & 29 & 1,44 \\
\hline 18 & Pompeiopolis (Zım.) & 7 & 24,1 & 0 & 0 & 16 & 55,2 & 0 & 0 & 6 & 20,7 & 29 & 1,44 \\
\hline 19 & Kastamonu Merkez & 2 & 8 & 0 & 0 & 16 & 64 & 1 & 4 & 6 & 24 & 25 & 1,25 \\
\hline 20 & Beldeğirmen Köyü & 1 & 5,26 & 0 & 0 & 15 & 79 & 0 & 0 & 3 & 15,8 & 19 & 0,95 \\
\hline 21 & Etnografya Müzesi & 2 & 20 & 0 & 0 & 8 & 80 & 0 & 0 & 0 & 0 & 10 & 0,5 \\
\hline & TOPLAM & & & & & & & & & & & 2008 & 100 \\
\hline
\end{tabular}

Araştırma bulgularının ikinci bölümünde aynı turistik noktaya ilişkin ziyaretçi ve kamu kurum fotoğrafları karşılaştırılarak incelenmiştir.

Fotoğraf 1. Horma Kanyonu

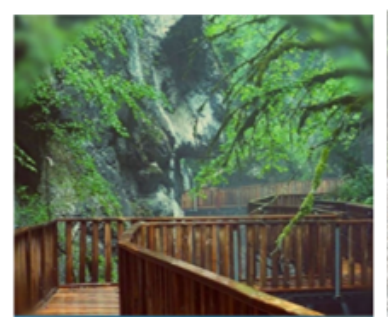

Ziyaretçi

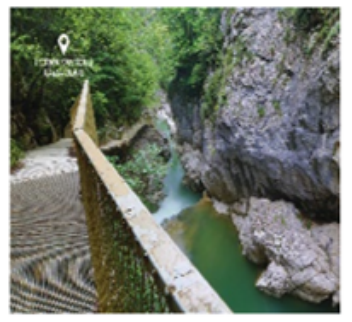

Belediye

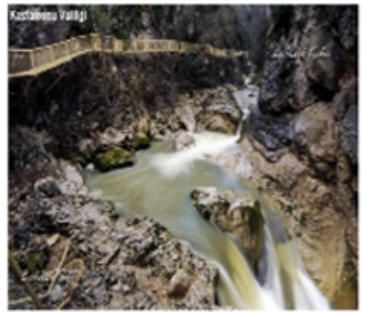

Valilik

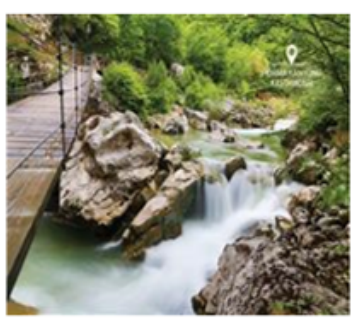

Ill Kültür ve Turizm $M$.

Horma Kanyonu ziyaretçilerin Kastamonu'da \%17,08 ile en çok fotoğraf paylaştığ1 yerdir. Ziyaretçilerin \%24,20 ile yeşil alan, \%46,65 ile de kanyonda bulunan ahşap yapımı yolların fotoğraflarını paylaştıkları tespit edilmiştir. İlk fotoğrafta ziyaretçiler kanyonun ahşap yolları ile doğal yeşilliğin birbiri ile olan uyumunu göstermeye çalışmışlardır. Fotoğrafta kanyonun doğallı̆̆ ilkbahar gösterimiyle vurgulanmıştır. Belediye, Valilik ve İl Kültür ve Turizm Müdürlüğü fotoğraflarında ahşap yürüme yollarının yanında su alanı da vurgulanmıştır. Bu durumda ziyaretçilerin kurumlardan farklı olarak kanyonda sonradan yapılmış olan üstyapı çalışmasına dikkat çektikleri görülmektedir. 
Fotoğraf 2. Ilgaz Dă̆ı Milli Parkı

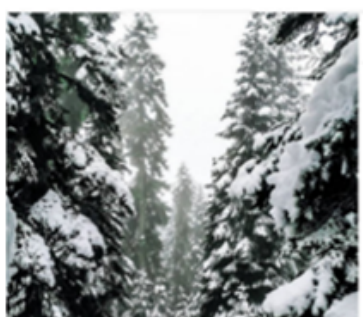

Ziyaretçi

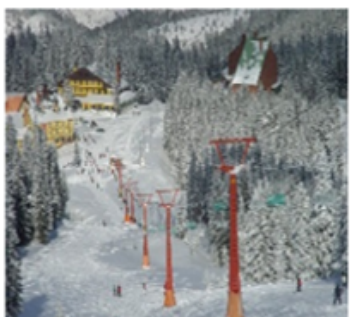

Belediye

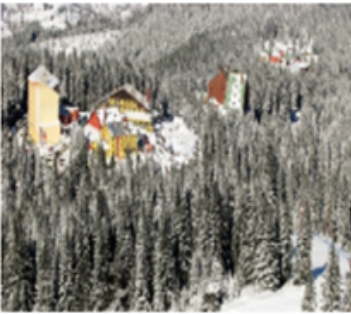

Valilik

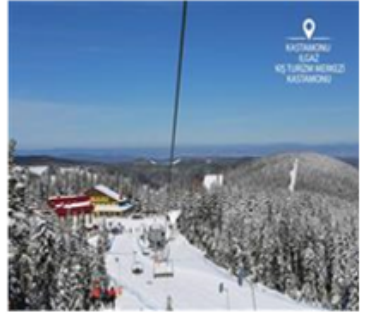

Il Kültür ve Turizm $M$.

Ilgaz Dağı Milli Parkı'nı ziyaret eden ve fotoğraflayan ziyaretçilerin çoğunlukla kış aylarını tercih ettiği görülmüştür. Ziyaretçilerin çektiği fotoğrafların arka planlarında karlı alan \%39,86, açık alan \%21,01 ve karışık alan \%19,20 oranına sahiptir. Ziyaretçilere ait olan fotoğrafta mevsimin kış olması nedeniyle arka fon manzara yerine karlı alan olarak nitelendirdiğimiz yakın bir ağaçlık alandan oluşmaktadır. Bu fotoğraf karesinde ziyaretçi kar kalınlığının yoğunluğunu ağacın üzerinde anlatmaya çalışmıştır. Ağaç renginin koyu ve kar renginin açık olmasından dolayı zıt renklerin oluşturduğu uyum ile daha belirgin duran doğal güzelliği ve kar kalınlığı göstermek istemektedir. Kastamonu Belediyesi, Valilik ve İl Kültür ve Turizm Müdürlüğünün resmî sitesinden alınan fotoğraflarda ise turistik tesisler ve doğanın karlı görünümü sergilenmektedir. Fotoğrafta yan anlam olarak ziyaret esnasında yapilabilecek etkinlik ile ticari alan vurgusu yapılmıştır.

Fotoğraf 3. İnebolu Plajı

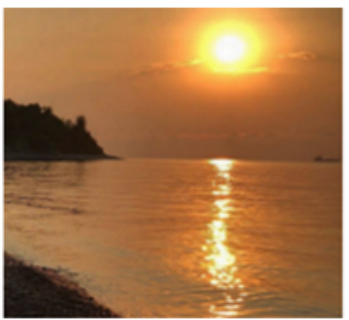

Ziyaretçi

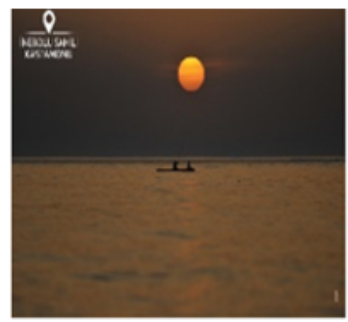

Belediye

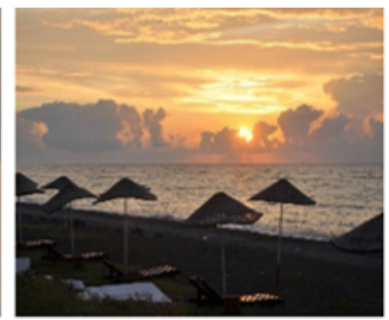

Valilik

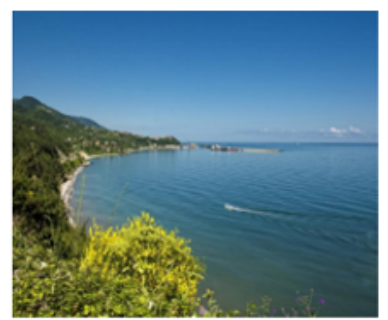

Il Kültür ve Turizm $M$.

En çok ziyaret edilen 3. bölge olan İnebolu plajında \%56,50 açık alan, 38,42 ile karmaşık alan fotoğraflarının gösterildiği tespit edilmiştir. Ziyaretçilerin paylaştığı ilk fotoğrafta günbatımı esnasında oluşan ışık ve renk uyumunun deniz yüzeyinde meydana getirdiği yansımalar gösterilmiştir. Ayrıca deniz alanına daha fazla yer ayırmak düz anlamı ifade ederken durgunluğuna vurgu yapılması yan anlamı belirtmektedir. Kastamonu Belediyesinin resmî sitesinden alınan fotoğrafta çok yakın benzerliğin olduğu tespit edilmiştir. Valilik resmî sitesinden alınan fotoğraf yine günbatımına yakın ancak plaj, kum vb. başka unsurları da içermektedir. Bu fotoğrafta ayrıca yan anlam olarak sahilde yapılabilecek etkinliklere işaret edilmekte diğer bir ifade ile ticari alan gösterilmektedir. İl Kültür ve Turizm Müdürlüğü fotoğrafında ise denizin ve gökyüzünün mavisi ile doğanın yeşilliği gösterilerek diğer paylaşımlardan farklı bir gösterim tespit edilmiştir. 
Fotoğraf 4. Küre Dă̆ları Milli Parkı

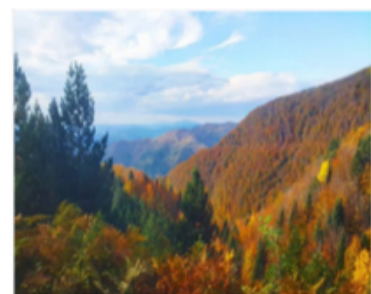

Ziyaretçi

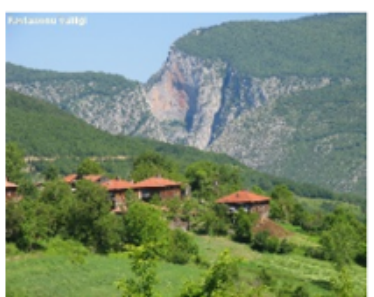

Belediye

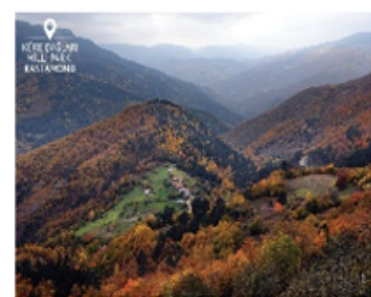

Valilik

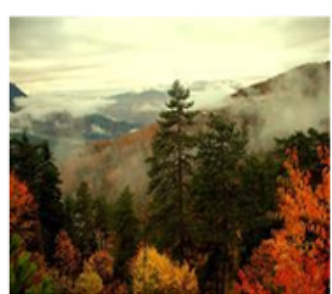

İl Kültür ve Turizm $M$.

Misafirler Küre Dağı Milli Parkı'nı daha çok $(\% 44,97)$ sonbahar aylarında fotoğraflarken, paylaşılan fotoğrafların ortak özelliği açık bir alana ait renkli orman manzarasıdır. İlk fotoğrafta da ziyaretçi gökyüzünün maviliği ile bulutların beyazlığı ve birçok sayısız renkten oluşan ormanın birleştiği ufuk çizgisini merkeze alarak renk çeşitliliğini göstermeye çalışmaktadır. Bu fotoğrafta çok renklilik ile neşeli bir ifade yan anlam olarak gösterilmiş olabilir. Belediye ve Valilik resmi sitelerine ait fotoğraflarda ilk görüntüye yakın bir gösterim olsa da fotoğraf karelerinde yerleşim alanlarının da vurgulandığı tespit edilmiştir. Bu durumda ziyaretçilerin yan anlam açısından tamamen doğal olanı göstermek istedikleri söylenebilir. İl Kültür ve Turizm Müdürlüğü fotoğrafının da ziyaretçi karesi ile aynı özellikleri taşıdığı ifade edilebilir.

\section{Fotoğraf 5. Gideros Koyu}

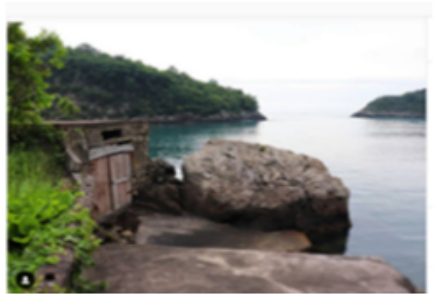

Ziyaretçi

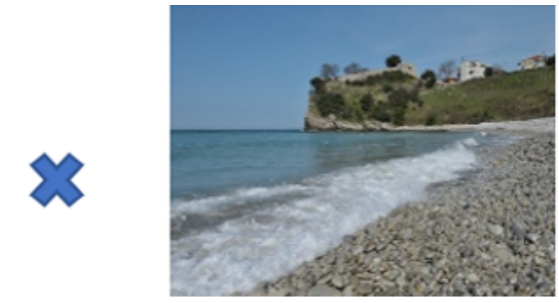

Valilik

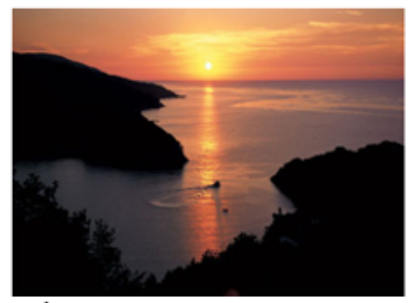

İl Kültür ve Turizm $M$.

Gideros Koyu'nda ziyaretçilerin en çok bölgeye adını veren koyu fotoğrafladığı tespit edilmiştir. Ziyaretçiler \%26,8 ile yeşil alan, \%29,3 ile karışık arka planları fotoğraflarında göstermiştir. İlk bakışta büyük bir kaya parçası göze batmasına rağmen genel olarak Gideros Koyu'nun sessizliği ve sakinliğini vurgulayan bir yan anlam ifadesi mevcuttur. Bu fotoğrafta koyun iki yakası da görüntülenmeye çalışılmıştır. Ziyaretçiler aynı fotoğrafı gün batımı ve genellikle havanın açık olduğu zamanları tercih ederek de göstermiştir. Kastamonu Valiliği'nin resmi sitesinde ise sahil ve deniz kıyısı görüntüsü vurgulanmaya çalışılmıştır. İl Kültür ve Turizm Müdürlüğü resmî sitesinde paylaşılan fotoğrafta günbatımı gösterimi dikkat çekmektedir. Belediye resmî sitesinde ise fotoğraf ile tanitıma rastlanmamıştır.

\section{Fotoğraf 6. Ginolu Plajı}

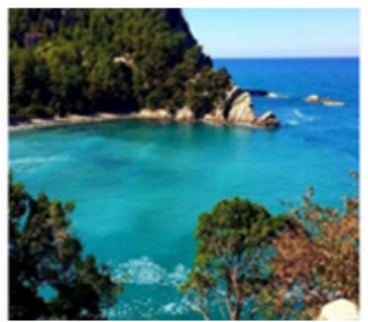

Ziyaretçi

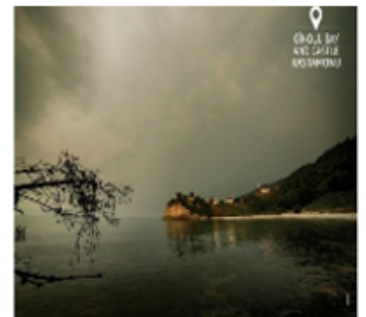

Belediye

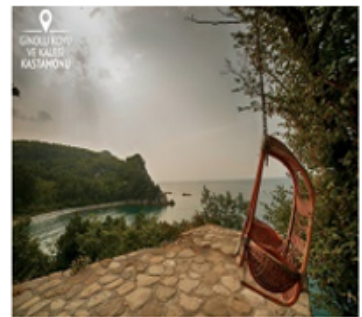

Valilik

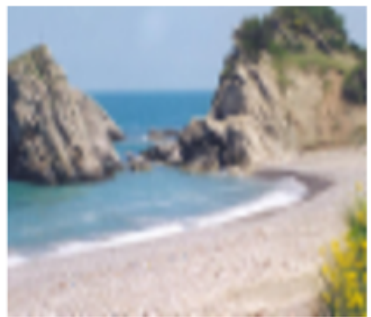

İl Kültür ve Turizm $M$. 
Ginolu Plajı'nda ziyaretçiler \%32,43 ile yeşil alan, \%35,14 ile karışık arka planları fotoğraflarında göstermiştir. İlk fotoğrafta plaja ait berrak bir su rengi ile yeşil ormanın gösterimi yapılmıştır. Çok temiz bir doğal güzelliğin bulunduğu düz anlam ifadesi bulunmaktadır. Denizin durgun ve temiz görüntüsü ile şehirden uzak rahat bir dinlenme alanı olduğu vurgulanmıştır. Belediye ile İl Kültür ve Turizm Müdürlügü̈nün fotoğraflarında plaj ve kumul alan daha çok ön plana çıarılmıştır. Deniz-kum- güneş üçlüsünün oluşturduğu alan vurgulanarak ziyaretçilere turistik çekicilikler gösterilmiştir. Valilik sitesinde ise doğal çekiciliğin yanında salıncak ile yapılabilecek bir etkinliğe dikkat çekilerek manzaraya daha tepeden hâkim olan dinlenme duygusu veren yan anlam ifadesi tespit edilmiştir.

\section{Fotoğraf 7. Valla Kanyonu}

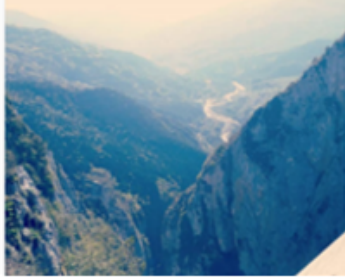

Ziyaretçi

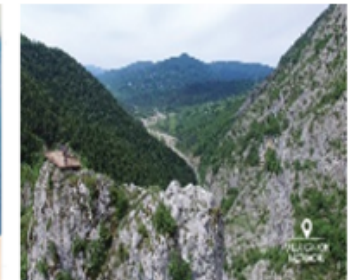

Belediye

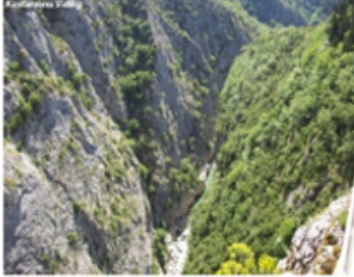

Valitik

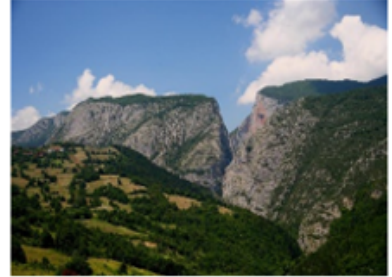

İl Kültür ve Turizm $M$.

Valla Kanyonu'nu ziyaret eden misafirler \%25 oranında kanyona ulaşmak için çıkılan merdiven ve ahşap yolu göstermekle birlikte \%37,84 gibi önemli bir çoğunluk açık alana işaret eden bölgenin jeolojik yapısının ön plana çıktığı kayalık ve vadinin iki yamacını göstermeyi tercih etmiştir. Ziyaretçiler kanyonun derinliğini fotoğrafın merkezine alarak bulundukları noktanın yüksekliğine ve görüş alanlarının büyüklüğüne vurgu yaparak kanyona ait manzarayı düz anlam ifadesi olarak göstermeye çalışmıştır. Bu gösterim Belediye resmî sitesinde yayınlanan fotoğraf ile benzer açıyı anımsatmaktadır. Valilik resmî sitesinden alınan fotoğraf ziyaretçi paylaşımı ile benzerlik gösterse de kanyonun sadece bir kısmı gösterilmiştir. İl Kültür ve Turizm Müdürlüğü resmî sitesinden alınan fotoğraf benzer açının daha uzaktan gösterimini oluşturmaktadır. Kurum fotoğraflarının ortak yönü kanyonun dik yamaçlarının birbirine yakın olduğu görkemli yapıyı göstermesi iken, ziyaretçi fotoğrafında kanyonun uçsuz bucaksız derinliğine dikkat çekilmiştir.

Fotoğraf 8. Loç Vadisi

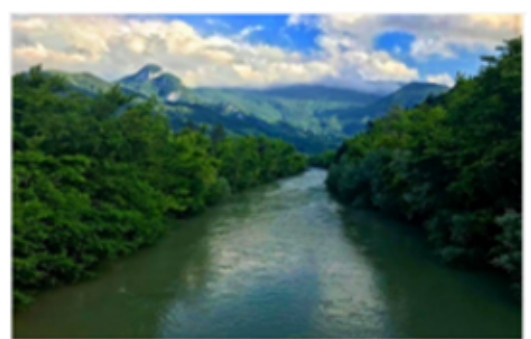

Ziyaretçi

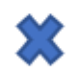

Belediye

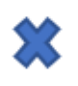

Valilik İl Kültür ve Turizm $M$.

Loç Vadisi paylaşılan fotoğraflar arasında 8. sırada olup en çok \%38,5 ile yeşil alan ve \%28,6 ile su bulunan alanların ağılıkta olduğu tespit edilmiştir. Ziyaretçiler debisi yüksek sayılabilecek nehir, yoğun ağaçlık alan ve beyaz bulutların aralığında mavi gökyüzünü göstermiştir. Fotoğrafta yan anlam olarak nehrin sessizce akışı ve ormanların sonsuzluğu vurgulanmaya çalışılmıştır. Belediye, Valilik ile İl Kültür ve Turizm Müdürlügü gibi diğer paydaşlar fotoğraf ile gösterimde bulunmamışlardır. Bu durumda üç resmi kurumun da fotoğraf gösteriminde bulunmaması dikkat çekicidir. 
Fotoğraf 9. Kurşunlu Han

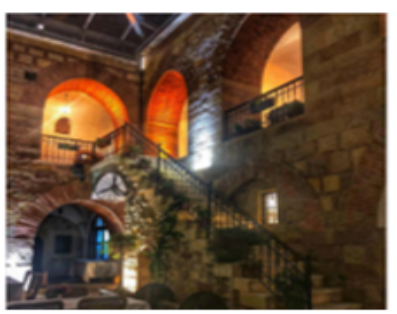

Ziyaretçi

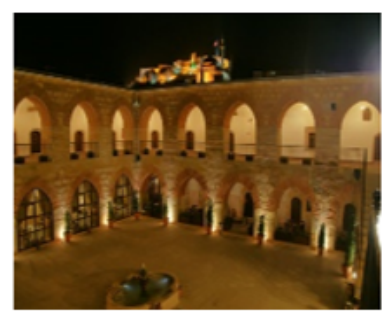

Belediye

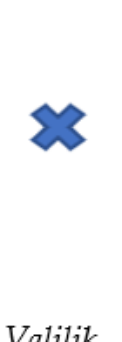

Valilik

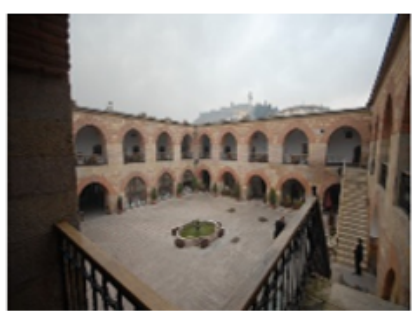

İl Kültür ve Turizm $M$.

Paylaşılan fotoğraflar içerisinde 9. sırada yer alan Kurşunlu Han'da \%44,44 oranı ile açık alan gösterimleri ön plana çıkmaktadır. \%20,83 ile de bina ve yapı alanı fotoğraf karesinde gösterilmeye çalışılmıştır. İlk fotoğrafta da görüldüğü gibi ziyaretçiler en çok merdivenleri arka plan olarak göstermeye çalışmışlardır. Bu gösterimde ziyaretçi, hanın tarihi dokusuna gönderme yapan duvarları ve kemerleri öne çıkararak hanın işlevselliğine vurgu yapmıştır. Belediye ile İl Kültür ve Turizm Müdürlüğü site fotoğraflarında ise hanın tamamını içine alan gösterimler yapılmıştır. Bu yaklaşımın hanın kullanımına işaret eden gösterimler olduğu söylenemez. Bu gösterimlerle handa işlevselliği geri planda kalmış bir görünüm sergilenmiştir. Valilik resmî sitesinde fotoğraf ile tanıtım yapılmamıştır.

\section{Fotoğraf 10. Şerife Bacı Anıtı}

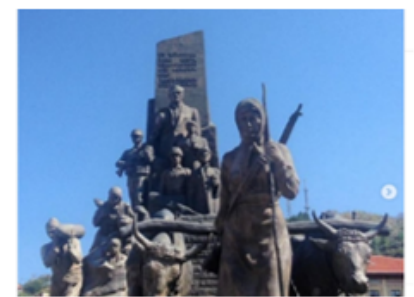

Ziyaretçi

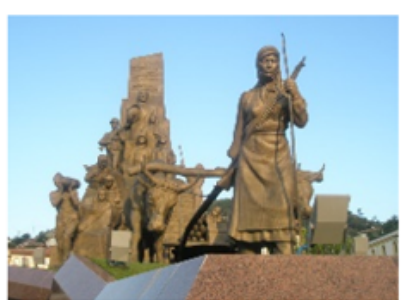

Belediye

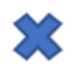

Valilik

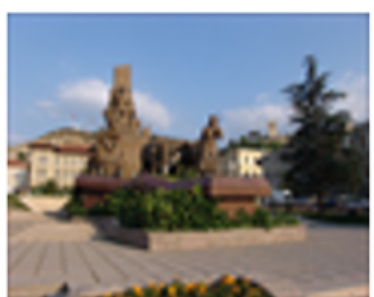

İl Kültür ve Turizm $M$.

Misafirler anıt fotoğrafının arka planına \%65,71 oranında açık alan gösterimini işaret ederek gökyüzünün maviliğini göstermeye çalışmışlardır. Fotoğrafların karesine anıtın tamamı alınmaya çalışılmış ve çoğunluğu ön cepheden ve kadın figürü merkeze alınarak gösterilmiştir. Anıtın yerden yüksekte ve büyük olması fotoğrafı gösterenin zorunlu olarak arka planı gökyüzü göstermek mecburiyetinde bırakmış olabilir. Belediyenin resmî sitesinden alınan fotoğrafta aynı açıdan çekilmiş olsa da anıtın etrafını çevreleyen mermer yapı da gösterime dahil olmuş ve yine açık alan olan gökyüzü, fotoğrafın arka planını kapsamıştır. İl Kültür ve Turizm Müdürlüğü resmî sitesinde ise net olmayan bir resim paylaşılmıştır. Valilik resmî sitesinde anıta ilişkin fotoğraflı tanıtım yapılmadığı tespit edilmiştir.

Fotoğraf 11. Ilgarini Mă̆rası

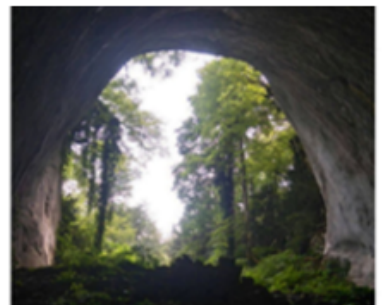

Ziyaretçi

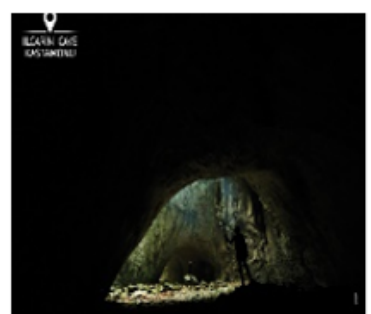

Belediye

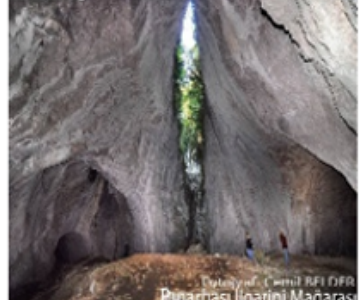

Valilik

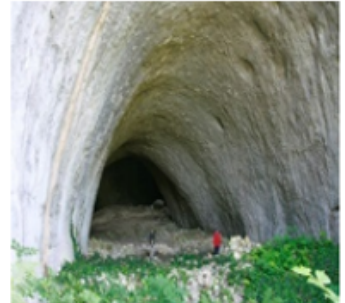

Ill Kültür ve Turizm $M$. 
Ilgarini Mağarası ziyaretçilerin \%48,2 ile en çok yeşil alan gösterimi yaptığı fotoğrafları içermektedir. Fotoğraflarda mağaraya girdikten sonra geriye dönük olarak giriş kapısının gösterimi paylaşılmıştır. Mağaranın içinden dışarıya doğru çekilen bu fotoğrafta mağaranın büyük görkemli duvarı, dışarıdaki ormanlık alan ve gün ışığının yansıması bir bütünlük halinde gösterilmeye çalışılmıştır. Mağaraya ait duvarlar fotoğrafın çerçevesi konumunda kalmıştır. Arkadan yansıyan güneş ışığı ise derinlik oluşturulmasına neden olmuştur. Bu durum arkadaki ağaçlar ile mağara girişinin ne kadar yüksek olduğunu da göstermektedir. Belediye, Valilik ile İl Kültür ve Turizm Müdürlüğü fotoğraflarında ise daha çok mağaranın taş duvarları gösterilmiştir. Mağara duvarının yanında diğer öğelerin de olması mağaranın büyüklüğünü daha iyi anlatabilmek için gereklilik olduğunu düşündürmektedir.

Fotoğraf 12. İstiklal Yolu

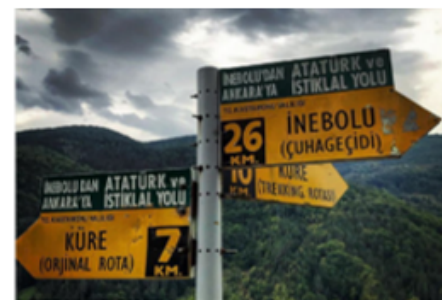

Ziyaretçi

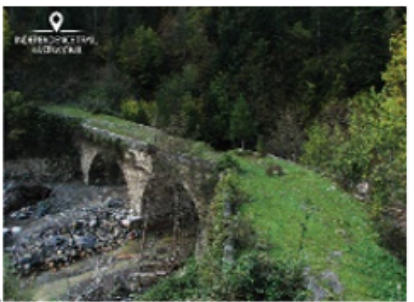

Belediye

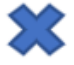

Valitik

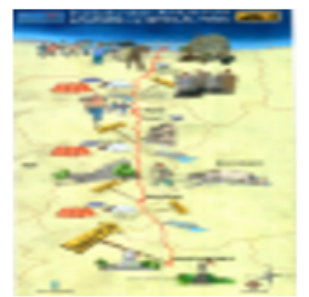

İ Kültür ve Turizm $M$.

İstiklal Yolu doğal yürüyüş alanını ziyaret eden turistler bu yolda ilerlediklerini kanıtlama isteği duyar gibi görünmektedir. Bu nedenle yazılı bir işaret levhasının önünde nereye gittiklerini göstermeye çalışmıslardır. Bu durum \%28,30 oranında yolda çekilen fotoğraflar ve $\% 26,42$ ile karışık alan fotoğrafları ile ön plana çıkmıştır. Tarihi bir değere sahip olan İstiklal Yolu rotası üzerinde bulunan yönlendirme işaretlerinin ziyaretçilerin ilgisini çektiği ve bulundukları yeri gösterme ihtiyacı hissettirdiği söylenebilir. Dolayısıyla ziyaretçi sadece bir doğa fotoğrafı olmadığını ifade eden bir yan anlam oluşturmaktadır. Belediye resmî sitesinden alınan fotoğraf tamamen farklılık göstermekte olup yeşil renkli az kullanılmış bir yolun köprünün üzerinden geçtiği halini yansıtmaktadır. İl Kültür ve Turizm Müdürlüğü resmî sitesinde fotoğraf olarak rota haritası gösterilmiştir. Ayrıca etkinliğe ait başka birçok fotoğraf mevcuttur. Valilik resmî sitesinde ilgili alana ait birçok etkinlik fotoğrafına rastlanmış ancak fotoğraflarda çok fazla ziyaretçinin bulunması yayınlama izini almayı zorlaştıracağından kullanılamamıştır.

Fotoğraf 13. Kastamonu Kalesi

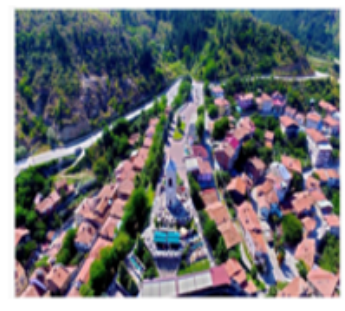

Ziyaretçi

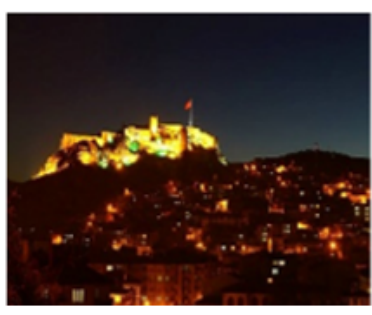

Belediye

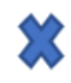

Valilik

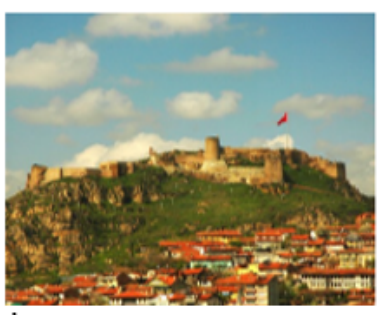

İl Kültür ve Turizm M.

Kastamonu Kalesi'ni ziyaret eden turistlerin \%78,9 gibi önemli bir çoğunluğu açı alan fotoğrafları paylaşmıştır. Fotoğrafta kaleden şehre doğru bir gösterim bulunmaktadır. Açık bir havada ilkbahar mevsimine işaret eden evlerin çatıları ve üstten bir görüntü ön plana çıkmaktadır. Bu gösterimler kalenin şehre oranla daha yüksek bir konumda bulunduğu ve etrafının açık bir manzaraya sahip olduğu izlenimini vermektedir. Bu bağlamda kaleyi ziyaret eden turistlerin kale yerine kaleden görünen diğer alanları göstermeyi tercih ettikleri söylenebilir. 
Diğer paydaşlardan paylaşımda bulunmayan Valilik hariç diğer iki fotoğrafta başka bir yerden kalenin bütününü gösteren kaleye doğru uzak bir fotoğraf çekilmiş olması düz anlam ifadesidir. $\mathrm{Bu}$ üç fotoğrafta da bayrak figürü fotoğrafın içerisinde yer alan ortak bir gösterim olarak tespit edilmiştir. Bu durumda bayrağa atıf edilen değerin yan anlam olarak gösterildiği söylenebilir.

Fotoğraf 14. Nasrullah Meydanı

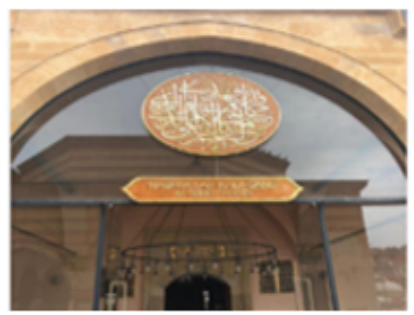

Ziyaretçi

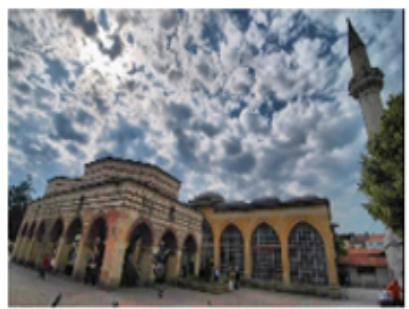

Belediye
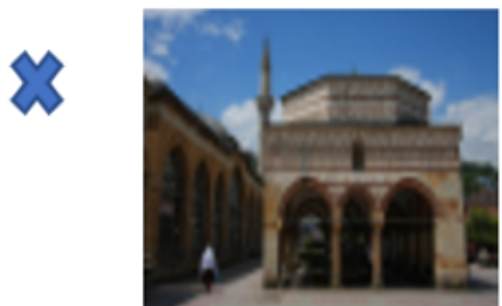

Valilik

İl Kültür ve Turizm $M$.

Nasrullah Meydanı'nı ziyaret eden turistler \%40,80 oranında caminin iç ve dış mekânından fotoğraf kareleri paylaşmıştır. İlk fotoğrafta caminin giriş kapısının üzerindeki cam alana Arapça yazılmış metin gösterilmiştir. Caminin su ve şadırvan alanı da \%28,6 gibi önemli bir oranda paylaşılmıştır. Belediye ile İl Kültür ve Turizm Müdürlüğü mimari yapının tamamını gösteren fotoğrafları paylaşmışlardır. Valilik resmî sitesinde konu ile ilgili yazılı bilgi bulunmakta olup fotoğraf kullanılmamıştır. Dolayısıyla ziyaretçilerin paylaştıkları fotoğraflar ile kurumsal paydaşlar arasında önemli farklılıklar mevcuttur.

Fotoğraf 15. Mahmut Bey Cami

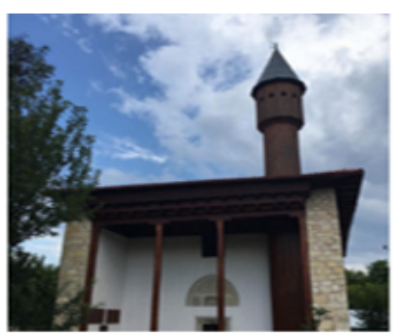

Ziyaretçi

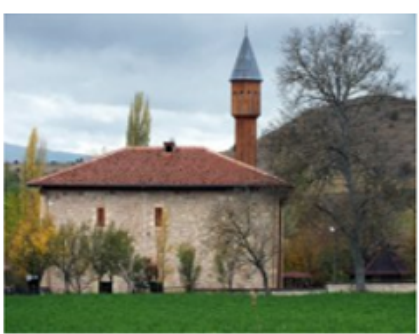

Belediye

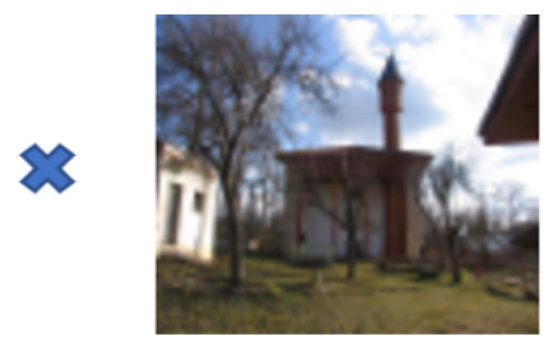

Il Kültür ve Turizm $M$.

Mahmut Bey Cami fotoğraflarında \%35,90 ile binanın dış cephesi ve \%33,33 ile iç cephe fotoğrafı paylaşılmıştır. Bu fotoğrafların yarıdan fazlasında ziyaretçinin kendisi fotoğraf karesinde yer almayıp yapının mimarisini göstermeye çalışmıştır. Özellikle dış cephe görüntülerinde giriş kısmı ahşap ve taş işçiliğin birlikte oluşturduğu bütünü ön plana çıkarmaya çalışan yakın bir fotoğraf ile gösterimde bulunulmuştur. Belediye ile İl Kültür ve Turizm Müdürlüğü uzaktan çekilen caminin dış cephe görüntüsü ile ziyaretçilerin bakış açlarına yakın bir gösterimde bulunmuş olsalar da belirgin bir mimari özelliği temsil eden gösterim oluşmamaktadır. Valilik resmi sitesinde cami ile ilgili fotoğrafa rastlanmamıştır.

Fotoğraf 16. Evkaya Mezarları

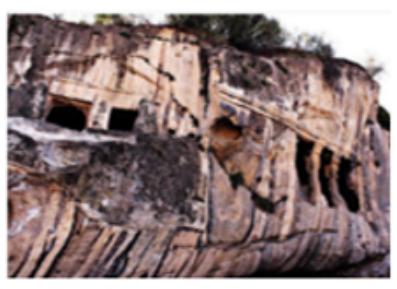

Ziyaretçi

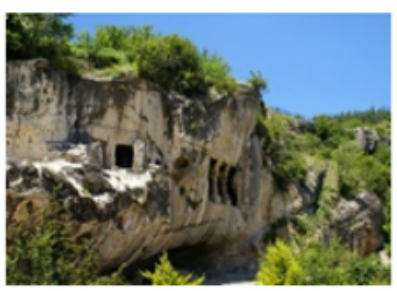

Belediye

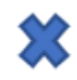

Valilik

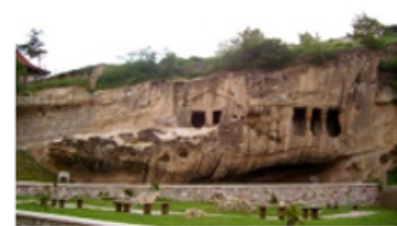

İl Kültür ve Turizm $M$. 
Evkaya Mezarları'nı ziyaret eden turistler \%71,43 gibi önemli bir oranda yapının dış cephe fotoğrafını paylaşmışlardır. Yapının içerisine girdiklerinde kendi fotoğraflarını da yapı ile birlikte içeriden dışarıya doğru görüntülemişlerdir. İçeriden çekilen fotoğrafların alanı tam olarak temsil etmediği tespit edilmiştir. Bu nedenle dış cephe fotoğrafı kullanılması tercih edilmiştir. Belediye ile İl Kültür ve Turizm Müdürlüğü fotoğrafları ziyaretçilerin gösterimleri ile büyük ölçüde benzerlik göstermektedir. Ancak daha uzaktan ve yapının tamamını içerisine alan gösterimler yapılmıştır. Valiliğin resmî sitesinde alan ile ilgili fotoğrafa rastlanmamıştır.

\section{Fotoğraf 17.Saat Kulesi}

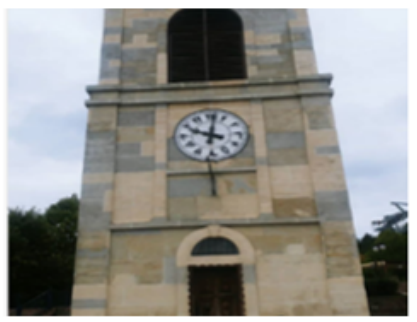

Ziyaretçi

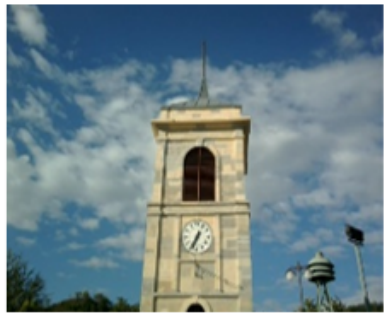

Belediye

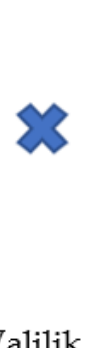

Valilik

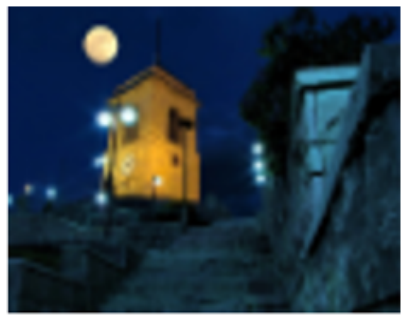

İl Kültür Turizm M.

Ziyaretçiler \%20,7 ile saat kulesini, \%31 kule ile birlikte görünümü ve \%31 ile karmaşık alan fotoğrafları paylaşmışlardır. Ziyaretçiler saat kulesinin tamamını fotoğraf karesine sığdıramamış dolayısıyla arka planda kulenin mimari yapısı ve özellikle kapı yönünden gösterimler yapılmıştır. Saat kulesinin ahşap özel tarihi bir görüntü veren kapısı ve kapı tokmağı vurgulanmaya çalışılmıştır. Karmaşık alan fotoğrafları birden fazla ziyaretçi ve fotoğrafı çekenler ile ilgisi olmayan diğer zorunlu olarak fotoğraf karesinde yer alan kişileri kapsamaktadır. Belediye resmî sitesinde de aynı yönden benzer bir fotoğraf bulunmakta ancak daha uzaktan kulenin tamamını içerisine alan bir gösterimde bulunulmuştur. Aradaki fark ziyaretçilerin daha çok mimari yapıya dikkat çekmesidir. İl Kültür ve Turizm Müdürlügü̈nün paylaşımında saat kulesi ile birlikte merdiven, aydınlatmalar, gece gökyüzü, ay vb. unsurlarda bulunmaktadır. Valilik resmî sitesinde saat kulesi ile ilgili paylaşımda bulunulmadığı görülmüştür.

Fotoğraf 18. Pompeipolis Taşköprü

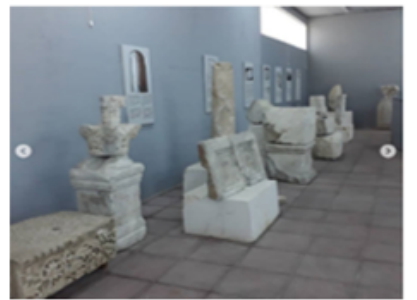

Ziyaretçi

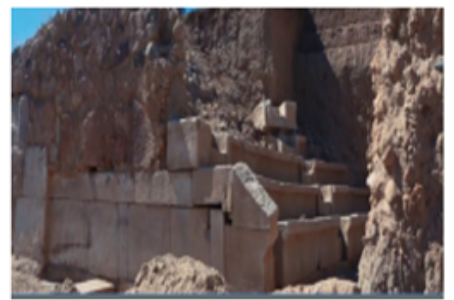

Belediye

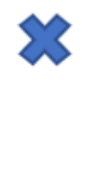

Valilik

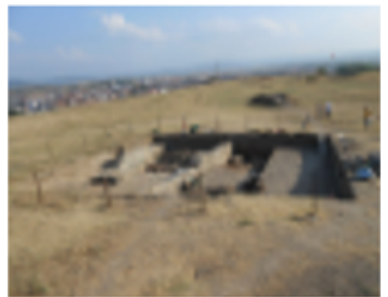

İl Kültür ve Turizm $M$.

Ziyaretçiler \%55,2 ile daha çok dış cephe fotoğrafı paylaşmışlardır. Bunun yanında \%24,14 ile iç cephe, \%20,69 ile açık alan fotoğrafı paylaşılmıştır. Dış cephe fotoğraflarında ziyaretçilerden arındırılmış bir örnek alınamadığı için iç cephe fotoğraf örneği verilmiştir. Bu örnekte de tarihi eserlerin görüntüleri dikkati çekmektedir. Ziyaretçi fotoğrafında bir tarihi eserin çok yakından çekilmiş gösterimi yapılmıştır. Belediye fotoğrafında da dışarıdan ve çok uzaktan çekilen bir fotoğraf ile gösterimde bulunulmuştur. İl Kültür ve Turizm Müdürlüğü uzaktan diş cephe gösteriminde bulunduğu tespit edilmiştir. Valilik resmî sitesinde ise fotoğraf paylaşımında bulunulmamıştır. 
Fotoğraf 19. Kastamonu Merkez

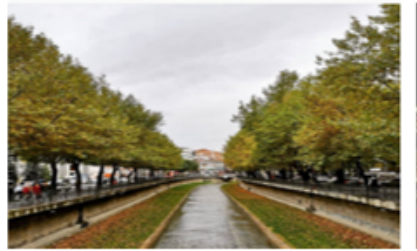

Ziyaretçi

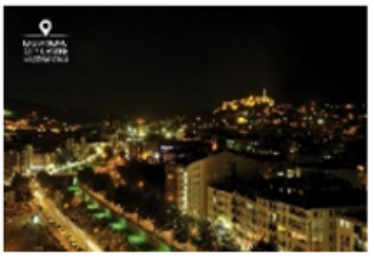

Belediye

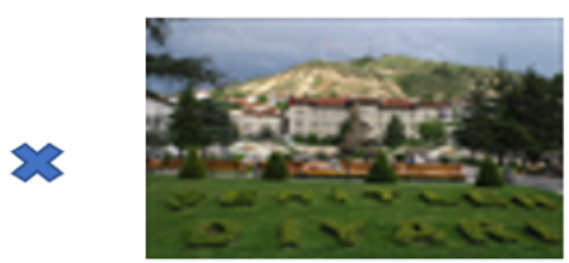

Valilik İl Kültür ve Turizm $M$.

Kastamonu merkezini ziyaret eden misafirlerin \%64 gibi önemli bir çoğunluğu fotoğraftaki gibi şehrin ortasından geçen nehir ve iki yanındaki ağaçların oluşturduğu perspektifi göstermeye çalışmıştır. Aynı açıdan \%25'e yakını gece ışıklandırma anı ile gösterilmiştir. Kış, kar ve her mevsimin ayrı özelliklerini içeren görüntüler gösterenin özellikle dikkat çektiği bir açı olmuştur. Belediye resmî sitesinden alınan fotoğrafta nehir, yol ve şehrin belirli bir kısmı uzaktan çekilen bir fotoğrafla gösterilmiştir. İl Kültür ve Turizm Müdürlügü'nde Kastamonu çok daha farklı bir fotoğraf ile temsil edilmiştir. Valilik resmî sitesinde ise alana ait fotoğraf paylaşımında bulunulmamıştır.

Fotoğraf 20. Beldeğirmen Köyü

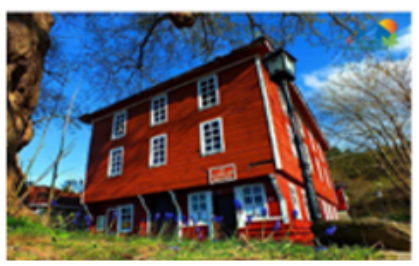

Ziyaretçi

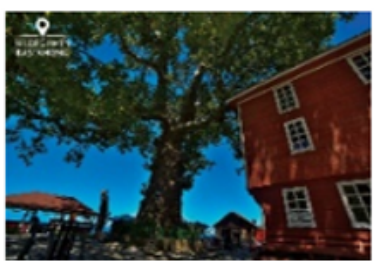

Belediye

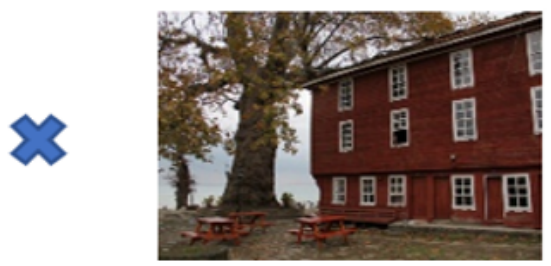

İl Kültür Turizm M.

Beldeğirmen Köyü sembolü haline gelmiş kırmızı renkli ahşap yapılı evin fotoğrafı \%79,0 ila bina gösterimi olarak sunulmuştur. Ziyaretçilerin paylaştığı fotoğrafta evin tamamı gösterilmekle beraber yakından çekilen bir açı bulunmaktadır. İl Kültür ve Turizm Müdürlüğü sitesindeki fotoğraf ziyaretçilerin paylaşımına oldukça yakın açılardadır. Kastamonu Belediyesi'nin resmî sitesinden alınan fotoğrafta aynı açıdan biraz daha uzaktan yapılan gösterimde ev ile birlikte büyük bir ağaç ve diğer unsurlar da gösterilmeye çalışılmıştır. Valilik resmî sitesinde bölge ile ilgili fotoğrafa rastlanmamıştır.

\section{Fotoğraf 21. Etnografya Müzesi}

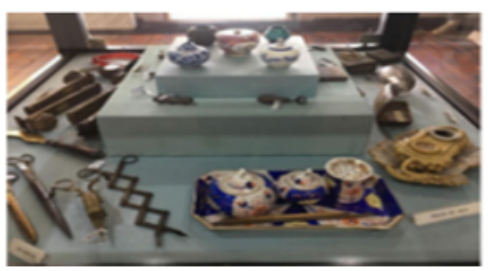

Ziyaretçi

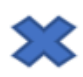

Belediye

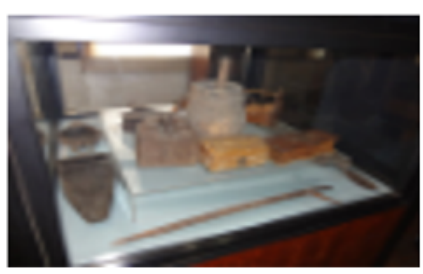

İ1 Kültür Turizm M.

Etnografya Müzesi'nde ziyaretçiler daha çok iç mekân fotoğraflarını paylaşarak sergilenen eşyaları göstermiştir. İl Kültür ve Turizm Müdürlüğü'nün resmî sitesinden alınan fotoğrafta da benzer iç mekân ve sergilenen eşyalar gösterilmiştir. Belediye ve Valilik resmi sitelerinde ise fotoğraf paylaşımı yapılmamıştır. Tüm fotoğraflarda düz anlam ifade eden doğrudan bir gösterim tespit edilmiştir. 
Araştırma bulgularının üçüncü bölümünde aynı turistik noktaya ilişkin ziyaretçi ve resmi kurum fotoğraflarının benzerlik ve farklılıkları Tablo 2' de bütün halinde incelenmiştir.

Tablo 2. Turistik Noktalara Ait Ziyaretçi ve Kamu Fotoğraflarının Karşılaştırılması

\begin{tabular}{|c|c|c|c|c|c|c|c|c|c|}
\hline \multirow{2}{*}{\multicolumn{2}{|c|}{ Bölgeler }} & \multicolumn{2}{|c|}{ Ziyaretçi } & \multicolumn{2}{|c|}{ Belediye } & \multicolumn{2}{|c|}{ Valilik } & \multicolumn{2}{|c|}{$\begin{array}{l}\text { Il Kültür ve } \\
\text { Turizm M. }\end{array}$} \\
\hline & & 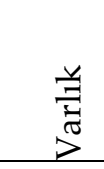 & 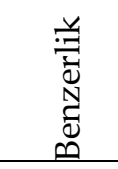 & 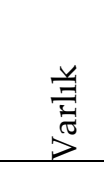 & 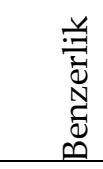 & 莺 & 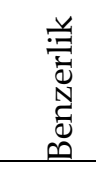 & 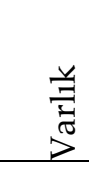 & 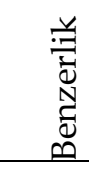 \\
\hline 1 & Horma Kanyonu & گ & $\Longrightarrow$ & گ & 㞋 & كُ & & گ & \\
\hline 2 & Ilgaz Dağı M.P. & طُ & & طُ & & طُ & & كُ & \\
\hline 3 & İnebolu Plajı & طُ & 㞋 & ط & ב & كُ & 㞋 & كُ & \\
\hline 4 & Küre Dağları M.P. & كُ & 㞋 & گ & 尼 & طُ & 尼 & طُ & 尼 \\
\hline 5 & Gideros Koyu & طُ & & $x$ & & طُ & & طُ & \\
\hline 6 & Ginolu Plajı & طُ & & كُ & & طُ & & ك & \\
\hline 7 & Valla Kanyonu & كُ & & كُ & & گ & & طץ & \\
\hline 8 & Loç Vadisi & كُ & & $x$ & & $x$ & & $x$ & \\
\hline 9 & Kurşunlu Han & طُ & & كُ & & $x$ & & طُ & \\
\hline 10 & Şerife Bacı Anıtı & طُ & & طُ & & ك5 & & كُ & \\
\hline 11 & Ilgarini Mağarası & ↔ & & كُ & & كُ & & كُ & \\
\hline 12 & İstiklal Yolu & كُ & & طُ & & $x$ & & طُ & \\
\hline 13 & Kale & گ & & كُ & & $x$ & & كُ & \\
\hline 14 & Nasrullah Meydanı & طُ & & طُ & & $x$ & & كُ & \\
\hline 15 & Mahmut Bey Camii & كُ & $\rightleftharpoons$ & كُ & 戸 & $x$ & & كُ & 戸 \\
\hline 16 & Evkaya Mezarı & طُ & 㞋 & كگ & 㞋 & $x$ & & گ & ट \\
\hline 17 & Saat Kulesi & طُ & 㞋 & كُ & ב & $x$ & & كُ & \\
\hline 18 & Zımbıllıtepe Höyüğü & كُ & & طُ & & $x$ & & طُ & \\
\hline 19 & Kastamonu Merkez & كُ & & كگ & & $x$ & & كک & \\
\hline 20 & Beldeğirmen Köyü & طૃ & ב & طُ & 㞋 & $x$ & & كُ & ב \\
\hline 21 & Etnografya Müzesi & كُ & 尼 & $x$ & & $x$ & & طُ & 㞋 \\
\hline
\end{tabular}

Tablo 2'ye göre ziyaretçilerin fotoğraf paylaştığ 21 turistik noktalardan üçünde (Gideros Koyu, Loç Vadisi, Etnografya Müzesi) Kastamonu Belediyesi resmî web sitesinde fotoğraflı tanıtımda bulunulmamıştır. Kastamonu Valiliği resmî web sitesinde de 12 turistik noktada fotoğraflı tanıtıma rastlanmamıştır. Ancak bazı haber başlıkları altında fotoğraflar mevcut olup turistik 
tanıtım amaçlı olmadığı düşünülmüş ve fotoğraf içerisinde çok sayıda ziyaretçi bulunması nedeniyle araştırmada kullanılamamıştır. İl Kültür ve Turizm Müdürlüğü resmî sitesinde ise turistik noktalardan birinde fotoğraflı tanıtımda bulunulmamıştır. Tüm fotoğraflar içinde sadece Küre Dağları Milli Parkı'na ait fotoğrafların tamamıla birbirine benzediği tespit edilmiştir. Belediye ve Valiliğin İnebolu Plajı́ndaki fotoğrafları benzerlik göstermektedir. Bunların dışında Mahmut Bey Camii ve Evkaya Mezarları fotoğrafları Belediye ile İl Kültür ve Turizm Müdürlüğü'ne oldukça benzer çekimleri oluşturmaktadır. Ziyaretçinin paylaştığı Etnografya Müzesi ile İl Kültür ve Turizm Müdürlüğü fotoğrafları benzerlik göstermektedir. Belediye ile İl Kültür ve Turizm Müdürlüğ̈̈'ne ait Beldeğirmen Köyü fotoğrafları da benzerlik göstermektedir. Dolayısıyla ziyaretçi fotoğraflarına benzerliğin az sayıda olduğu söylenebilir.

Ayrıca bazı turistik noktalarda bölgeye ait karakteristik fotoğraflar tespit edilmiştir. Bunların; Ilgaz Dağları- kar, Küre Dağları-sonbahar, İnebolu Plajı-günbatımı, Horma Kanyonu-ahşap yürüme yolları, Gideros Koyu-sessizlik ve sakinlik, Ginolu Plaji-sessizlik ve sakinlik, Ilgarini Mağarası-mağara kapısının ters açıdan çekilmesi, İstiklal Yolu-yol işaretleri, Nasrullah Camicami giriş kapısı, Beldeğirmen Köyü-kırmızı ev, Kastamonu merkez-nehir ve perspektif gibi çok belirgin öne çıkan ve hatırlatıcı etkisi olabilecek güçlü noktalar olduğu söylenebilir.

\section{SONUÇ ve ÖNERILER}

Araştırmada ziyaretçilerin Kastamonu'daki 21 turistik noktaya ait Instagramda en sık paylaştıkları fotoğraf kareleri göstergebilim aracılı̆̆ıyla incelenmiştir. Ayrıca ziyaretçi fotoğrafları ile resmî kurumların tanıtımda kullandıkları fotoğraflar karşılaştırılmıştır. Bu fotoğraflar kendi içerisinde beş gruba ayrılıp kodlanmış ve yorumlanmıştır. Toplamda 2008 adet fotoğraf incelenmiş ve en çok fotoğraf paylaşımı yapılan ilk beş turistik nokta Horma Kanyonu (\%17,8), Ilgaz Dağı Milli Parkı (\%13,75), İnebolu Plajı (\%8,81), Küre Dağları Milli Parkı $(\% 8,42)$ ve Cide Gideros Koyu $(\% 7,82)$ olarak tespit edilmiştir. Bu beş nokta Kastamonu'da paylaşılan fotoğrafların yarısından fazlasını oluşturmaktadır.

Loç Vadisi gibi paylaşım sıklığı açısından 8. sırada yer alan bir turistik noktada kurumların fotoğraflı tanıtımlarda bulunmaması dikkat çekici bir durum olup destinasyon yöneticilerinin göz önünde bulundurması gereken önemli bir değer olduğu ifade edilebilir. Dolayısıyla ziyaretçilerin paylaştığ fotoğraflar yol gösterici olmakla beraber Godfrey ve Gretzel (2010:312) şehirlerin markalaşmasında fotoğraf ve sosyal medyanın rolünün dikkate alınması gerektiğini belirtmiştir. Yine aynı araştırmacılar daha çok fotoğraflı tanıtım yapılması, hatta kurumların fotoğraf kullanmadığı destinasyonlar için de fotoğraf oluşturup sayılarını arttırması gerektiğini belirtmiştir. Başka bir çalışmada (Rickley-Body ve Knudsen, 2012:5) ise turistlerin farklı bakış açlarına sahip olabilecekleri ve dolayısıyla bilgilendirici levhaların özellikle yabancı turistlere uzun çeviriler yapılmadan daha öz bir biçimde aktarılması gerektiği önerilmiştir. Böylelikle çalışmada tanıtımın turist merkezli olması gerektiği sonucunu ortaya çıkmaktadır. Bu durumda turiste sorulabilecek en basit sorunun; "Destinasyon ile ilgili ne öğrenmek istiyorsunuz?" olması gerekir. Ziyaretçilerin paylaştığı destinasyon fotoğrafları da bu soruya cevap niteliğinde olup ziyaretçilerin ilgilerini yansıttığından değerlendirilmeye alınması kaçınılmazdır.

$\mathrm{Bu}$ araştırmada paylaşılan fotoğraflarda ilk sekiz sırada doğal çekiciliklerin bulunduğu tespit edilmiştir. Dokuzuncu sıradan itibaren doğal çekicilikler ile beraber kültürel miras unsurlarının paylaşıldığ belirlenen 21 turistik noktadan en az fotoğraf paylaşımı yapılan yerler olarak tespit edilmiştir. Turistik noktalardan Kastamonu Belediyesi üç, Kastamonu Valiliği 12, İl Kültür ve Turizm Müdürlüğü bir alanda fotoğraf ile tanıtımda bulunmamıştır. Kurum fotoğraflarında Ilgaz Dağı Milli Parkı'nda olduğu gibi kurumlar yapılabilecek etkinlikleri göstermeye çalışırken ziyaretçiler 
daha sade fotoğraflar tercih etmişlerdir. Bu durumda kurum fotoğraflarının yanında ziyaretçi fotoğraflarının da sitelerde bulundurulması önerilebilir. Horma Kanyonu'nda ziyaretçi fotoğraflarıyla kurumların fotoğrafları birbirine yakın olsa da ziyaretçi fotoğrafında kanyona sonradan yapılan ahşap yürüyüş yolunun tasarımı vurgulanmış, kurumlarda ise daha çok doğal alan vurgulanmıştır. Dolayısıyla ziyaretçilerin yapılan hizmeti beğendikleri söylenebileceği gibi kurumlarında bu hizmetlerini ön plana çıarmaları gerektiği düşünülebilir.

Araştırmada belirlenen turistik çekiciliklere özgü ortak noktalar olduğu görülmüş̧ür. Bunlar; İnebolu Plajında gün batımı, Küre Dağlarında özellikle sonbahar fotoğrafları, Kastamonu merkezde nehrin perspektifi destinasyona özgü karakteristik fotoğraflardır. Bu durumu pazar segmentleri açısından açıklayan araştırmacılar (Pennington ve Thomsen, 2010:49), işaret-nesne ilişkisinin parametrelerini özgünlük, aşinalık, sembolizm, sosyal ve kültürel anlamlar belirleyerek bir temsilin üzerindeki etkisinin daha iyi tahmin edilebileceğini belirtmişlerdir. Yine aynı araştırmada ulusal markalaşma analizleri ile işaret-nesne ilişkisi pazarlama alanında dikkate alınması gereken bir durum olarak belirtilmiştir. Dolayısıyla İnebolu Plajı karakteristik fotoğrafının gün batımı olduğu söylenebilir. Diğer bir araştırmada turist fotoğraflarının destinasyon hakkında daha ikonik anlamlar verebileceği belirtilirken turist merceğinden pazarlama fikirlerinin oluşabileceği de eklenmektedir (Davila ve Gretzel 2011:9). İkonik anlamlar veren bu noktaları göstergebilim açısından yan anlam olarak açıklamaya çalışan diğer bir araştırmada ise gün batımının her insan için değişik anlamlara gelebileceği, bazıları için hüzün bazıları için aşk ve romantizm ve fotoğrafın durumuna göre sıcak bir güneşin varlığını anlatabileceği belirtilmiştir (Çulha, 2011:421). Bu neyin pazarlanmak istendiğine göre değişiklik gösterebilmektedir.

Doğal çekiciliklerin yanında kültürel değerlerin de ön plana çıtığı bu araştırmada ziyaretçiler tarihi hanların sadece müze olarak işlev görmediğini aynı zamanda yaşayan bir değer olduğunu yansıtan fotoğraflar paylaşmıştır. Bu duruma örnek bir araştırmada sosyal medyada destinasyon yönetim örgütleri fotoğraflı tanıtımlar yaparken gösterilen yiyecek içecek bile olsa konum bilgisinin mutlaka eklenerek iletişim yaklaşımı geliştirilmesi gerektiğini belirlmiştir (Golinvaux ve Evagelou, 2017:313). Modern mimari eserlerini web sitesinin tam merkezine yerleştiren bir pazarlama uygulamasında ise şehre gelen turistler için bu mimari eserin zamanla ziyaretçileri için ana destinasyon olmaya başladığı görülmüştür (Godfrey ve Gretzel, 2010:10). Bu durumu takiben başka bir çalışmada da kurumların sosyal medya üzerinden yaptıkları fotoğraf paylaşımlarına bölgenin değerleri ve kimliğine uygun logo ve slogan eklenerek fotoğrafın daha kapsamlı konuşlanmasına yardımcı olunabileceği belirtilmiştir (Golinvaux ve Evagelou, 2017:323). Bu bağlamda Kastamonu klasik mimari örneklerinden olan tarihi konakların veya hanların değerlendirilmesi düşünülmelidir. Tarihi konaklar şehirde yalnızca görülmesi gereken bir obje olmayıp şehir kimliği ile eş anlamlı ve ziyaretçiler tarafından yaşanması gereken ikonik bir değer anlamına gelebilir.

Kurum fotoğrafları incelendiğinde, paylaşımlarında etkinliklere daha çok yer verdikleri görülmüştür. Turistler ile yapılan etkinliklerin takip edilmesi olumlu olmakla birlikte çok uzaktan çekilmiş topluluk fotoğrafları yerine yakın plan mutlu ve eğlenen insan figürleri daha etkili olabilir. Doğru fotoğrafları belirlemede ziyaretçi fotoğraflarını incelemek önemli bir katkı sağlayabilir. (Davila ve Gretzel 2011:9). Bu nedenle kurum fotoğraflarında genel kuşbakış1 fotoğraflar ile birlikte aynı bölge için ziyaretçilerin fotoğrafları da paylaşılabilir. Paylaşılan fotoğraflar aralıklarla güncellenebilir.

Ziyaretçiler mimari yapılarda yapının bir kısmını veya tamamımın yakın kareden gösterimini paylaşırken, kurumlar daha uzaktan ve yapı dışında diğer öğeleri de içine alan gösterimde bulunmuşlardır. Diğer taraftan anıtsal yapıların büyük olması fotoğraf karesi içerisinde yer almasını da zorlaştırmaktadır. Bu nedenle anıtların bulunduğu meydanlarda fotoğraf karesinin 
uygun olabileceği birkaç noktanın işaretler ile belirlenmesi ziyaretçiler için daha uygun olabilir. Buna ilaveten kurumların sitelerinde anıtsal yapılar ile ilgili bir fotoğrafın paylaşımı uzaktanyakına ve dıştan-içe birkaç örnekle gösterilebilir.

Ziyaretçilerin paylaştıkları fotoğraflara benzer olan kurum fotoğrafları Küre Dağları Milli Parkı, İnebolu Plajı, Mahmut Bey Camii, Saat Kulesi, Evkaya Mezarlığı ve Beldeğirmen Köyü'dür. Bunların dışındaki fotoğraflar yarı benzerlik göstermektedir. Kastamonu Kalesi'nde olduğu gibi ziyaretçi paylaşımının tam tersi perspektifte olan kurum fotoğrafları da mevcuttur. Fotoğraflar kişiye özgü nesnel bir değer taşımaktadır. Bu nedenle ziyaretçinin fotoğraf karesindeki açıya yakın gösterimleri yakalamak oldukça zordur. Dolayısıyla bu araştırmada da benzerlik taşımayan turistik nokta fotoğraflarının bulunması doğal kabul edilebilir. Ancak destinasyon yönetim örgütlerinin sosyal medya fotoğraf ve öz çekimlerini sistemli bir şekilde analiz etmeleri yararlı olabilir. $\mathrm{Bu}$ analizin yapılmasında ziyaretçilerin bakış açılarını anlayabilmek adına göstergebilim yol gösterici olabilir. Analizler sonucunda elde edilen çıkarımlar, kurumsal sitelerdeki paylaşımların güncellenmesi esnasında kullanılabilir. Kurumlara karakteristik fotoğrafları daha ön plana çıkarmaları ve ziyaretçinin bakış açısını yakalamayı hedef edinmeleri gerektiği önerilebilir.

Araştırmanın son bir yılın fotoğraflarını içermesi kısıtlılık sayılabilir. Gelecek araştırmalarda farklı zaman serileri ile karşılaştırma yapılarak destinasyonun dönemsel trendleri tespit edilebilir. Farklı sosyal medya kanallarında paylaşılan fotoğraflar incelenebilir. Spesifik gruplara hitap eden belirli sosyal medya kanallarında paylaşılan fotoğraflar ile genele hitap eden fotoğraflar karşılaştırılabilir. Araştırmada mevsimsel paylaşımlara göre analizlerin yapılabilir, fotoğrafların aldığı beğeni ve yorumlarda kullanılan dil göstergebilim aracılı̆̆ıyla değerlendirilebilir ve dil ile fotoğraf uyumu incelenebilir.

\section{KAYNAKÇA}

Barthes, R. (1986). Göstergebilim İlkeleri (çev. B.FV., M.R.), (1.bs.) İstanbul: Sözce Yayınları.

Barthes, R. (2005). Göstergebilimsel Serüven (çev. B.V., M.R.), (4.bs.) İstanbul: Yapı Kredi Yayınları.

Bayram, M., Keleş, Y. ve Bayram, Ü. (2016). Çevrimiçi fotoğraflar üzerinden görsel destinasyon imajının incelenmesi: Erzincan doğa sporları örneği. I. Ulusal Alternatif Turizm Kongresi (07-09 Nisan 2016), 101-110.

Bedir Erişti, D. (2019). Yeni Medya ve Görsel İletişim Tasarımı, Pegem Akademi, Kızılay, Ankara. Çulha, O. (2011). Gösterge Bilim (Semiyotik) Tekniği Kullanılarak Kanada Fotoğraflarının İncelenmesi. ZKÜ Sosyal Bilimler Dergisi, 7 (13). 409-424.

Davila Rodriguez, M.A. and Gretzel, U. (2011). Seeing Old San Juan, PR through the Lenses of Tourists and Residents: An Analysis of User-Generated Photographs. Travel and Tourism Research Association: Advancing Tourism Research Globally, (32). 1-11.

Fatani, M., N., and Suyadnya, I., W., (2015) Beyond User Gaze: How Instagram Creates Tourism Destination Brand? Procedia- Social and Behavioral Sciences, 211, 1089 - 1095.

Godfrey, A.N. and Gretzel, U. (2010). The Use of Modern Architecture in City Marketing. Travel and Tourism Research Association: Advancing Tourism Research Globally, 33, 1-12. 
Golinvaux, A. and Evagelou, I. (2017). The Role of Semiotics in Tourism Destination Braniding Through Social Media: The Case of Switzerland. Journal of Tourism Research Review of Tourism Sciences, (16). 2003-216.

Guerrero, P., Moller, M. S., Olafsson, A. S. and Snizek, B. (2016). Revealing cultural ecosystem services through Instagram images: The potential of social media volunteered geographic information for urban green infrastructure planning and governance. Urban Planning, 1(2), 1-17.

Guiraud, P. (1999). Göstergebilim (çev: M.Y.), (2.bs.) Ankara: İmge Kitabevi.

Hunter, W. C., Chung. N., Gretzel, U. and Koo, C., (2015). Constructivist Research in Smart Tourism. Asia Pacific Journal of Information Systems, 25 (1), 105-120.

Kastamonu İ Kültür ve Turizm Müdürlüğü (2019) Genel bilgiler https://kastamonu.ktb.gov.tr/TR-91025/genel-bilgiler.html Erişim Tarihi: 28.12.2019

Knudsen, D., C. and Boyd, R., J. (2011). Tourism Sites as Signs. Travel and Tourism Research Association: Advancing Tourism Research Globally, 74, 1-6.

Kuzey Anadolu Kalkınma Ajansi (KUZKA) www. kuzka. gov.tr_16_DY 3Y51PJ_02kastamonu.pdf. Erişim Tarihi: 15.12.2019

Lee, E., Lee, J. A., Moon, J., H. and Sung, Y., (2015). Pictures speak louder than words: Motivations for using Instagram. Cyberpsychology, behavior, and social networking, 18(9), 552-556.

Mukhina, K., D., Rakitin, S., V. and Visheratin, A., A., (2017). Detection of tourists attraction points using Instagram profiles. Procedia computer science, 108, 2378-2382.

Parsa, S., ve Parsa, A., F., (2004). Göstergebilim Çözümlemeleri, (2.bs.) İzmir: Ege Üniversitesi Basımevi.

Pennington,j., W., and Thomsen, R.,C.,(2010). A Semiotic Model of Destination Representations Applied to Cultural and Heritage Tourism Marketing. Scandinavian Journal of Hospitality and Tourism, 10 (1), 33-53.

Picazo, P., and Moreno-Gil, S., (2017). Analysis of the projected image of tourism destinations on photographs: a literature review to prepare for the future. Journal of Vacation Marketing, 25(1), 324.

Rickley-Boyd, J., M. and Knudsen, S., C., (2012). Semiotics, Identity, Ideology and Tourism Destination Marketing. University of Massachusetts Amherst Scholar Work and UMass Amherst, (6). $1-6$.

Shuqair, S., and Cragg, P., (2017). The immediate impact of Instagram posts on changing the viewers' perceptions towards travel destinations. In 1st International Conference on Advanced Research (ICAR-2017).

Sığırcı, İ., (2016). Göstergebilim Uygulamaları, Metinleri- Görselleri- Olayları Okuma (2.bs.) Ankara: Seçkin Sosyal Bilimler. 
Stepchenkova, S., and Zhan. F., (2011). DMOs and User-Generated Photography: Comparison of Projected and Perceived Destination Images Using Perceptual Maps. University of Massachusetts Amherst Scholar Work and UMass Amherst, (48). 1-9.

Şahin, S., (2001). Göstergebilim ve Tarihsel Gelişimi, Dil ve Eğitim Dergisi, (21), 50-57.

Wikipedia (2019). Etiket Kavramı, https://tr.wikipedia.org/wiki/Hashtag Erişim Tarihi: 15.12.2019

Yıldırım, A., ve Şimşek, H., (2016). Sosyal bilimlerde nitel araştırma yöntemleri. Genişletilmiş 10. Baskı, Ankara: Seçkin Yayıncılık.

Zhang, K., Chen, Y., and Li, C., (2019). Discovering the tourists' behaviors and perceptions in a tourism destination by analyzing photos' visual content with a computer deep learning model: The case of Beijing. Tourism Management, 75, 595-608. 